\title{
SPATIAL AND MULTIVARIATE ANALYSIS OF TRACE ELEMENTS IN THE SURFACE WATER AND DEEP SEDIMENTS OF FRESH WATER AQUATIC ECOSYSTEM
}

\author{
${ }^{1}$ Kantha Deivi Arunachalam, ${ }^{1}$ Sathesh Kumar Annamalai, \\ ${ }^{1}$ Kamesh Viswanathan Baskaran, ${ }^{2}$ S. Rajaram, ${ }^{3}$ S.K. Jha and ${ }^{2}$ Sreedevi \\ ${ }^{1}$ Center for Environmental Nuclear Research, Directorate of Research, SRM University, Chennai-603203 Tamil Nadu, India \\ ${ }^{2}$ Environmental Survey Laboratories, Bhabha Atomic Research Centre, Kalpakkam 603102, India \\ ${ }^{3}$ Environmental Assessment Division, Bhabha Atomic Research Center, Trombay, Mumbai-400085, India
}

Received 2014-02-20; Revised 2014-02-22; Accepted 2014-03-26

\begin{abstract}
The aim of this study was to assess the levels of various trace metals present in water and sediment of fresh water aquatic ecosystem during the post monsoon season. The study was extended to identify the trace metal contamination in the water and sediment samples collected along the shores of Lambapur and Peddagattu the tribal villages in India using an Inductively Coupled Plasma Optical Emission Spectrometer (ICPMS). The trace metal contents in water samples were copper- 24.2 to 47.5 , chromium- 4.4 to 8.2 , cadmium- 0.1 to 0.3 , lead- 2.1 to 3.8, Nickel- 5.9 to 9.7, Zinc- 4.6 to 9.7 , Manganese- 10.8 to 13.2 , Iron- 52.9 to $157.2\left(\mu \mathrm{g} \mathrm{L}^{-1}\right.$ ) cobalt and arsenic were in BDL and the values were within the limits of Indian drinking water standards (BIS 10500: 1991). The trace metals concentration in the sediment samples ranged from $\left(\mathrm{mg} \mathrm{kg}^{-1}\right)$ : Copper- 61.5 to 113.7, chromium- 138.4 to 177.5 , cobalt- 33.2 to 42.7 , cadmium- 1.0 to 2.1 , lead- 57.9 to 103.4 , Nickel- 36.1 to 56.6 , Zinc- 51.2 to 102.1 , Manganese- 610.8 to 1301.7 and Iron- 2.5 to $2.9 \%$. In our study, four reliable indices such as Enrichment factor, Contamination factor, Geoaccumulation Index and Pollution Load Index were applied to estimate metal pollution and the results comparison are discussed below. The data generated were used to determine the quality of the sediments based on the enrichment factor, contamination factor and degree of contamination, geochemical index and Pollution Load Index (PLI).
\end{abstract}

Keywords: Enrichment Factor, Pollution Load Index, Nagarjuna Sagar Dam, Contaminant Factor

\section{INTRODUCTION}

Sediments that enter a reservoir may contain materials from geological formations within the catchment area and organic substances originating from decomposed plant and animal remains (Karbassi et al., 2011; Wang et al., 2007; Zhang and Shao, 2013). Therefore, sediments within reservoirs can act as sensitive indicators for monitoring the contaminants in aquatic environments. Since sediments play a very important role in physicochemical and ecological dynamics, any change in toxic concentrations of heavy metal residues on the sediments will affect the natural aquatic life support systems (Orebiyi et al., 2010). Sediments have polluted with various kinds of hazardous substances, including trace metals (Harikumar et al., 2009). The study of sediment cores have shown to be an excellent tool for establishing the effects of anthropogenic and natural processes on depositional environments (Vinodhini and Narayanan, 2008; Wang et al., 2007). The concentration of organic matter increases gradually within reservoirs, thereby affecting the quality of water and potentially changing the oxidation state into an anoxic condition. The conditions conducive to reduction together with low $\mathrm{pH}$ result in the mobilization of metals from the sediment to the water column (Biati et al., 2010). This may lead to

Corresponding Author: Kantha Deivi Arunachalam, Center for Environmental Nuclear Research, Directorate of Research, SRM University, Chennai-603203 Tamil Nadu, India 
serious changes in water quality because of the continuous interactions that commonly occur at the sediment-water interface (Barreto et al., 2008; Comero et al., 2014; Garizi et al., 2011). Different natural and artificial sources of pollution can pollute the environment with heavy metals (Dobra et al., 2006).

Nagarjuna Sagar Dam (NS Dam) built on the river krishna is the tallest masonry dam globally, with a maximum height of $124.7 \mathrm{~m}$ at the deepest portion of the river valley. The dam spreads over five districts in the Andhra Pradesh state of India, namely Nalgonda, Mahaboobnagar, Kurnool, Prakasam and Guntur. The Krishna River flows through a Nature reserve over a distance of $130 \mathrm{~km}$ within the Andhra Pradesh state and is a major source for irrigation and domestic use. The Atomic Mineral Division (AMD) identified new deposits of uranium at Lambapur and Peddagattu located in Pedda Adsarlapalli Mandal of Nalgonda district at a distance of about $135 \mathrm{~km}$ from Hyderabad andhra Pradesh state, India (Reddy et al., 2003). The deposits are known to exist at the unconformity contact between granitic basement and overlaying srisailam quartzite at Lambapur (Jha et al., 2012; Sartandel et al., 2009). There is the potential for this area to develop into a future uranium mining center (Verma et al., 2011). The granitic rocks of the Lambapur area in Nalgonda district of Andhra Pradesh state, India, contain uranium in the range of 10.2-116 ppm with an average of $35 \mathrm{ppm}$ and thorium in the range of 25.5-60: $7 \mathrm{ppm}$ with an average of $50 \mathrm{ppm}$ (Brindha et al., 2011; Raghavendra et al., 2013).

The area within Lambapur and Peddagattu containing the uranium deposits is drained by rivulets, which eventually flow into the Nagarjuna Sagar Dam (Reddy et al., 2003). The contribution of naturally occurring radionuclides and trace metals originating from the catchment of the dam would reflected in the sediment of Nagarjuna Sagar Dam. The sediment survey provides information on long term contamination trends and the environmental radionuclide concentration within different matrices. The trace metal concentrations within sediments are found to be higher because of the contribution of trace metals by rivulets draining into the reservoir. As a result, investigation of both water and sediment quality is required to assess the quality of reservoir water (Sartandel et al., 2009).

The main objective of this study was to determine the trace metal concentrations $(\mathrm{Cd}, \mathrm{Cr}, \mathrm{Cu}, \mathrm{Fe}, \mathrm{Ni}, \mathrm{Pb}, \mathrm{Se}$, $\mathrm{Co}, \mathrm{As}, \mathrm{Zn}$ ) in water and sediments within the shores of Peddagattu and Lambhapur the tribal village areas of nalgonda district andhra Pradesh, India. The results obtained from this study have value in providing information on background levels of metals in the water

and sediment of the reservoir, contributing to the effective monitoring of both environmental quality and the health of the organisms inhabiting the reservoir ecosystem. The study was carried out during the premonsoon period, March 2010.

\section{MATERIALS AND METHODS}

\subsection{Study Area}

Nagarjuna Sagar, known in ancient days as Vijayapuri, is located $150 \mathrm{~km}$ from Hyderabad and is one of the most prominent Buddhist centers and tourist spots in Andhra Pradesh. Nagarjuna Sagar Dam is the world's largest masonry dam with a height of $124.7 \mathrm{~m}$, creating a reservoir with a capacity of up to $11,472 \times 10^{6} \mathrm{~m}^{3}$ of water. It is situated at $16^{\circ} 50^{\prime} \mathrm{N}$ latitude and $79^{\circ} 20^{\prime} \mathrm{E}$ longitude. The leaching of uranium deposits by rivulets occurs in the study area within Lambapur and Peddagattu which experience hot climate during summer (April and May) with ranging temperatures from 30 to $46.58^{\circ} \mathrm{C}$ and 16 and $29.8^{\circ} \mathrm{C}$ in winter. The average annual rainfall is $\sim 500 \mathrm{~mm}$ occurring mostly during southwest monsoon (Raghavendra et al., 2013). Therefore, the sediment and water samples were collected from the shores of Lambapur and Peddagattu for our study.

Ten sampling points were selected based on the criteria that the sampling point should be around $500 \mathrm{~m}$ away from the shore and the sampling point should receive runoff from the shores of Lambapur and Peddagattu throughout the season. Table 1 shows a list of the chosen sampling points with their position and Fig. 1 shows the sampling locations within the map of the study area.

\subsection{Sampling}

Undisturbed surface sediment samples can provide an immediate assessment of the present levels of contamination in the area in relation to the textural and geo-chemical characteristics of the sediment. Triplicate sediment samples were collected from ten different locations as shown in Fig. 1 and Table 1. The depths at which sediment samples collected ranged from 49.5138.6 feet. The sediment samples from deeper regions of the reservoir were collected using a Van Veen Grab Sampler (Norinco Pvt. Ltd., Chennai) and stored in precleaned and acid rinsed PVC covers under cold temperatures for further analysis (Abdel-Gawad et al., 2012). The surface water samples were collected from $10-15 \mathrm{~cm}$ below the water surface using acid washed PVC cans. The water samples were filtered through 0.45 $\mu \mathrm{m}$ PTFE filter and immediately acidified using $3 \mathrm{~mL}^{-1}$ of $70 \%$ nitric acid per liter of sample. 


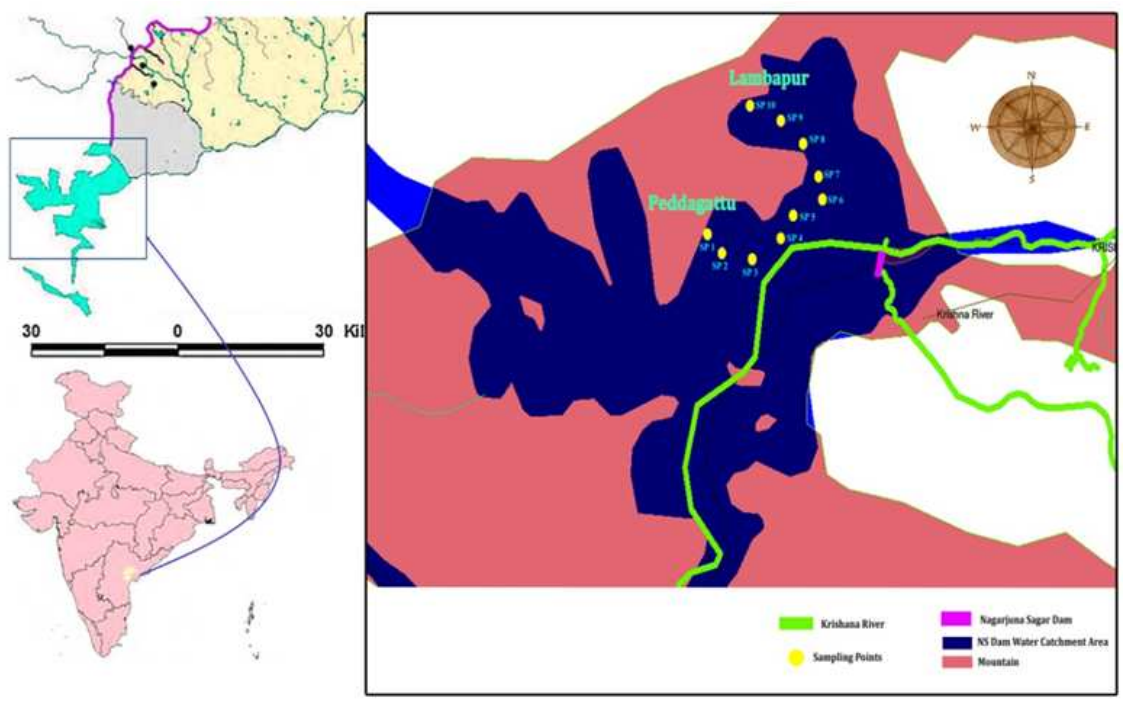

Fig. 1. Location of sampling sites within Nagarjuna Sagar Dam andhra Pradesh

Table 1. Sample coordinates from Nagarjuna Sagar dam

\begin{tabular}{lllr}
\hline $\begin{array}{l}\text { Sample } \\
\text { station }\end{array}$ & Latitude & Longitude & $\begin{array}{l}\text { Sampling depth } \\
\text { (feet) }\end{array}$ \\
\hline SP1 & $16^{\circ} 35^{\prime} 12.69^{\prime \prime} \mathrm{N}$ & $79^{\circ} 13^{\prime} 24.84^{\prime \prime} \mathrm{E}$ & 138.6 \\
SP2 & $16^{\circ} 34^{\prime} 37.11^{\prime \prime} \mathrm{N}$ & $79^{\circ} 13^{\prime} 57.96^{\prime \prime} \mathrm{E}$ & 95.7 \\
SP3 & $16^{\circ} 34^{\prime} 24.51^{\prime \prime} \mathrm{N}$ & $7^{\circ} 14^{\prime} 51.58^{\prime \prime} \mathrm{E}$ & 108.9 \\
SP4 & $16^{\circ} 34^{\prime} 52.62^{\prime \prime} \mathrm{N}$ & $7^{\circ} 15^{\prime} 45.79^{\prime \prime} \mathrm{E}$ & 108.9 \\
SP5 & $16^{\circ} 35^{\prime} 20.42^{\prime \prime} \mathrm{N}$ & $7^{\circ} 16^{\prime} 25.23^{\prime \prime} \mathrm{E}$ & 84.1 \\
SP6 & $16^{\circ} 35^{\prime} 52.55^{\prime \prime} \mathrm{N}$ & $7^{\circ} 16^{\prime} 54.25^{\prime \prime} \mathrm{E}$ & 108.9 \\
SP7 & $16^{\circ} 36^{\prime} 37.29^{\prime \prime} \mathrm{N}$ & $79^{\circ} 16^{\prime} 59.25^{\prime \prime} \mathrm{E}$ & 117.0 \\
SP 8 & $16^{\circ} 37^{\prime} 12.05^{\prime \prime} \mathrm{N}$ & $7^{\circ} 16^{\prime} 28.89^{\prime \prime} \mathrm{E}$ & 49.5 \\
SP 9 & $16^{\circ} 37^{\prime} 41.60^{\prime \prime} \mathrm{N}$ & $79^{\circ} 15^{\prime} 44.02^{\prime \prime} \mathrm{E}$ & 72.6 \\
SP 10 & $16^{\circ} 37^{\prime} 59.14^{\prime \prime} \mathrm{N}$ & $79^{\circ} 14^{\prime} 47.33^{\prime \prime} \mathrm{E}$ & 26.4 \\
\hline
\end{tabular}

In addition, $5 \mathrm{~mL}^{-1}$ of Chloroform was added per 10 liter of water sample in order to prevent microbial growth and the water samples were stored at $4^{\circ} \mathrm{C}$ until further analysis for its physio chemical and trace metal concentrations (Ong et al., 2009). All the collected samples cooled in ice soon after collection and then transported. Care is taken to avoid contamination of the sample during sampling, handling and transport to the laboratory.

\subsection{Microwave Digestion of Sediment Samples}

The sediment samples were dried in a hot air oven at $105^{\circ} \mathrm{C}$ for $2-3$ days until a constant weight was obtained and subsequently ground to a powder using a glass mortar and stored in precleaned polythene zip lock bags (Jumbe and Nandini, 2009). $0.5 \mathrm{~g}$ of sediment samples were digested using a CEM MARS-5 microwave oven (CEM Corp., Matthews, NC) with a 12-position HP-1500

Plus vessel and rotor system. The sample was digested using $1600 \mathrm{w}$ power with the ramp time of $10 \mathrm{~min}$. After cooling to room temperature, all the digests were filtered through $0.45 \mu \mathrm{m}$ PTFE filter and diluted to $50 \mathrm{~mL}^{-1}$ with ultrapure water and stored in polyethylene vials at $4^{\circ} \mathrm{C}$ untilanalysis in AAS and the blank was prepared without sample (Harzdorf et al., 1998; Muratli et al., 2012).

\subsection{Analysis of Water Samples}

About 2.5 liter of water sample was digested with $70 \% \mathrm{HNO}_{3}$ and $35 \% \mathrm{HCl}$ on a hot plate at $105^{\circ} \mathrm{C}$. The residue was dissolved by adding $0.5 \mathrm{M} \mathrm{HCl}$ and the contents were filtered through $0.45 \mu \mathrm{m}$ PTFE filter.The filtered contents were made up to $50 \mathrm{~mL}^{-1}$ with $0.5 \mathrm{M}$ $\mathrm{HCl}$ and analyzed by Inductively Coupled Plasma Optical Emission Spectrometry (ICPOES) (Perkin Elmer Optima 5300 DV) at Sophisticated Analytical Instrument Facility (SAIF), the Indian Institute of Technology, Madras, Chennai. (Arunachalam et al., 2013).

\subsection{Quality Assurance}

The quality of chemical analysis and the accuracy of the data were monitored using the Sediment Reference Materials purchased from International Atomic Energy Agency, Austria. (IAEA-SL-1-Trace and Minor Elements in Lake Sediment). The analytical results of the trace metals of the samples showed a good agreement with the analytical values of the reference materials. In addition, the recoveries rates are shown in Table 2 for the selected metals from the standard reference material were in the range of 95.91-115.73\%. 
Table 2. Quality assurance for analysis of sediment samples

\begin{tabular}{lccc}
\hline Element & $\begin{array}{l}\text { Certified reference } \\
\text { value } \mathrm{mg} / \mathrm{kg})\end{array}$ & $\begin{array}{l}\text { Measured } \\
\text { value }(\mathrm{mg} / \mathrm{kg})\end{array}$ & $\begin{array}{l}\text { Recovery } \\
(\mathrm{In} \%)\end{array}$ \\
\hline Copper & 36.00 & 36.76 & 102.11 \\
Chromium & 104.00 & 102.72 & 98.77 \\
Cobalt & 21.30 & 24.65 & 115.73 \\
Lead & 37.70 & 38.13 & 101.14 \\
Nickel & 44.90 & 43.91 & 97.80 \\
Zinc & 223.00 & 213.79 & 95.87 \\
Manganese & 3460.00 & 3284.00 & 94.91 \\
Iron & 67400.00 & 64250.00 & 95.33 \\
\hline
\end{tabular}

Two replicates of the homogenized filtered water samples were subjected to recovery studies by spiking samples using metal standards of about the same concentrations of the analytes of interest; the resulting mixtures were then subjected to the same digestion and analysis procedure (Oyoo-Okoth et al., 2010). The metals recovery ranged from $82-94 \%$. A blank was run for each digestion procedure to correct the measurements and to check all reagents and procedures for interferences and cross contamination.

\subsection{Calculation of the Enrichment Factor (EF)}

EF was calculated to determine whether the metal concentrations in the sediments collected from the shores of Peddagattu and Lambapur and the surrounding aquatic environment were of anthropogenic origins. To evaluate the magnitude of contaminants in the environment, the enrichment factors were computed relative to the abundance of species in source material to that found in the earth's crust (Zakir et al., 2008). To identify the anomalous metal concentration, geochemical normalization of the trace metals data to a conservative element, such as $\mathrm{Fe}$, was employed. Iron was selected because it is a major sorbent phase for trace metals and is a quasi-conservative tracer of the natural metal bearing phases in fluvial and coastal sediments (Hasan et al., 2013). Several authors have successfully used iron to normalize trace metal contaminants (Hasan et al., 2013; Martins et al., 2012; Muñoz-Barbosa et al., 2012). The following formula described in Equation 1 was used to calculate the $\mathrm{EF}$ value.

$$
\mathrm{EF}=\frac{\left({ }^{\mathrm{C}_{\text {metal }}} / \mathrm{C}_{\mathrm{Fe}}\right)_{\text {Sediment }}}{\left({ }^{\mathrm{C} \text { metal }} / \mathrm{C}_{\mathrm{Fe}}\right)_{\text {Control }}}
$$

Where:

$$
\begin{aligned}
\left(\mathrm{C}_{\text {metal }}\right)_{\text {Sediment }}= & \text { Concentration of the particular metal } \\
& \text { in sediment } \\
\left(\mathrm{C}_{\mathrm{Fe}}\right)_{\text {Sediment }}= & \text { Concentration of Iron in sediment } \\
\left(\mathrm{C}_{\text {metal }}\right)_{\text {Control }}= & \text { Control value concentration of the } \\
& \text { particular metal of the unpolluted } \\
& \text { environment in the Earth crust }
\end{aligned}
$$

$$
\begin{aligned}
\left(\mathrm{C}_{\mathrm{Fe}}\right)_{\text {Control }}= & \text { Control value concentration of iron of } \\
& \text { the unpolluted environment in the } \\
& \text { Earth crust }
\end{aligned}
$$

EF values were interpreted as suggested by (Taylor, 1964) where $\mathrm{EF}<1$ suggests no enrichment, $1 \leq \mathrm{EF}<3$ is minor; $3 \leq \mathrm{EF}<5$ is moderate; $5 \leq \mathrm{EF}<10$ is moderately severe; $10 \leq \mathrm{EF}<25$ is severe; $25 \leq \mathrm{EF}<50$ is very severe; and $50 \leq \mathrm{EF}$ is extremely severe. The EF calculation seeks to reduce the metal concentration viability associated with variations in sediment/sand ratios and is a convenient tool for plotting geochemical trends across large geographical areas.

\subsection{Contamination Factor $(\mathrm{CF})$ and Degree of Contamination $\left(\mathbf{m C}_{\mathrm{d}}\right)$}

The contamination degree $\left(\mathrm{C}_{\mathrm{d}}\right)$ aims to provide a measure of the degree of overall contamination within the surface layers in a particular sampling site. Hakanson (1980) had suggested an overall indicator of contamination based on interpreting the data by a contamination factor $\mathrm{C}_{\mathrm{f}}^{\mathrm{i}}$ of a given Trace metal as described in Equation 2 and the degree of contamination $\left(\mathrm{mC}_{\mathrm{d}}\right)$ to describe the degree of contamination as described in Equation 3:

$$
\begin{aligned}
& \mathrm{C}_{\mathrm{f}}^{\mathrm{i}}=\frac{\mathrm{c}_{0-1}^{\mathrm{i}}}{\mathrm{C}_{\mathrm{n}}^{\mathrm{i}}} \\
& \mathrm{mC}_{\mathrm{d}}=\sum_{\mathrm{i}=1}^{7} \mathrm{C}_{\mathrm{f}}^{\mathrm{i}} / \mathrm{n}
\end{aligned}
$$

Where:

$\mathrm{N}=$ Number of analyzed elements and

$\mathrm{I}=\mathrm{i}^{\text {th }}$ element (or pollutant)

$\mathrm{C}_{\mathrm{f}}^{\mathrm{i}}=$ Contaminant Factor of specific metal

$\mathrm{C}_{0-1}^{\mathrm{i}}=$ Mean value of the specific metal

$\mathrm{C}_{\mathrm{n}}^{\mathrm{i}}=$ Reference value for the metal

The Classification of contamination factor and contamination degree is given in Table 3.

\subsection{Geo-Accumulation Index $\left(I_{\text {geo }}\right)$}

The most common approach for estimating the enrichment of metal concentration above background is by the Geo-accumulation index $\left(\mathrm{I}_{\mathrm{geo}}\right)$. This index was introduced by Müller (1981) in order to determine and define metal contamination in sediments by comparing current concentrations with pre-industrial levels. The Geoaccumulation index $\left(\mathrm{I}_{\text {geo }}\right)$ is used by most of the researchers for trace element studies in soils and sediments (Hasan et al., 2013; Hou et al., 2013; Jumbe and Nandini, 2009; Zahra et al., 2014), is defined in Equation 4: 


$$
\mathrm{I}_{\text {geo }}=\log _{2} \frac{\mathrm{C}_{\mathrm{n}}}{1.5 \times \mathrm{B}_{\mathrm{n}}}
$$

where, $C_{n}=$ measured concentration of the metal examined $\left(\mathrm{mg} \mathrm{kg}^{-1}\right), \mathrm{B}_{\mathrm{n}}=$ geochemical background value $\left(\mathrm{mg} \mathrm{kg}^{-1}\right)$ (Turekian and Wedepohl, 1961). The constant $1.5=$ the background matrix correction factor owing to lithogenic variations in the sediment (Stoffers et al., 1986). This method assesses the degree of metal pollution in terms of seven enrichment classes based on the increased value of the index as $\mathrm{I}_{\text {geo }}<0$ is not contaminated, $<1$ is Not Contaminated to Moderately contaminated, $<2$ is Moderately contaminated, $<3$ is Moderately to highly contaminated, $<4$ is Highly contaminated, $<5$ is Highly to very highly contaminated, $<6$ is Very highly contaminated.

\subsection{Pollution Load Index (PLI)}

The Pollution Load Index (PLI) is an empirical index, which provides a simple method for assessing the level of trace metal pollution. Tomlinson et al. (1980) had employed a simple method based on the PLI to assess the extent of pollution by metals within estuarine sediments (Qiao et al., 2013; Varol, 2011). Sediment PLI was calculated using Equation 6 and the individual contamination factor for each metal is determined using Equation 5:

$$
\mathrm{CF}=\frac{\mathrm{C}_{\text {metal }}}{\mathrm{C}_{\text {Background }}}
$$

Sediment PLI is determined by:

$$
\mathrm{PLI}=\sqrt[n]{\mathrm{Cf}_{1} \times \mathrm{Cf}_{2} \times \mathrm{Cf}_{3} \times \ldots \ldots \times \mathrm{Cf}_{\mathrm{n}}}
$$

Where:

$\mathrm{CF}=$ The contamination factor

$\mathrm{C}_{\text {metal }}=$ The concentration of pollutant in sediment

$\mathrm{C}_{\text {background }}=$ The background value for the metal, the total number of metals is represented by $n$

Table 3. Classification of contamination factor and contamination degree

\begin{tabular}{lll}
\multicolumn{3}{c}{ contamination degree } \\
\hline $\mathrm{C}_{\mathrm{f}}^{\mathrm{i}}$ & $\mathrm{mC}_{\mathrm{d}}$ & Pollution status \\
\hline $\mathrm{C}_{\mathrm{f}}^{\mathrm{i}}<1$ & $\mathrm{mC}_{\mathrm{d}}<1.5$ & Very low degree of contamination \\
$1 \leq \mathrm{C}_{\mathrm{f}}^{\mathrm{i}}<3$ & $1.5 \leq \mathrm{mC}_{\mathrm{d}}<2$ & Low degree of contamination \\
$3 \leq \mathrm{C}_{\mathrm{f}}^{\mathrm{i}}<6$ & $2 \leq \mathrm{mC}_{\mathrm{d}}<4$ & Moderate degree of contamination \\
$\mathrm{C}_{\mathrm{f}}^{\mathrm{i}}>6$ & $4 \leq \mathrm{mC}_{\mathrm{d}}<8$ & High degree of contamination \\
- & $\mathrm{C}_{\mathrm{d}}>8$ & Very high degree of contamination \\
\hline
\end{tabular}

The PLI value is interpreted as polluted where PLI $>1$ whereas PLI $<1$ indicates no pollution. This index allows comparison between the several estuary systems.

\subsection{Spatial Analysis of Trace Metals}

Magesh et al. (2011) has described the spatial analysis of trace element contamination in sediments. The geospatial distribution of trace element contents was accomplished by a spatial analysis module in ArcGIS. An Inverse Distance Weighted (IDW) algorithm was used to interpolate the data spatially and to estimate values between measurements. The Inverse Distance Weighting (IDW) is an algorithm for spatially interpolating, or estimating values between measurements and implemented in ARCGIS 10.2 GIS software. Each value estimated in an IDW interpolation is a weighted average of the surrounding sample points. Using concentrations of heavy metals or the factor scores produced by PCA as variables with spatial interpolation techniques to create various continuous surfaces to determine the pollution patterns influenced by each potential pollution source. Weights are computed by taking the inverse of the distance from an observation's location to the location of the point being estimated (Mathes and Rasmussen, 2006). Many researchers have reported that IDW with a squared distance term yielded results most consistent with the original input data (Acosta et al., 2011; Delgado et al., 2010; He et al., 1997; Li et al., 2013; Lima et al., 2003; Zamani-Ahmadmahmoodi et al., 2013).

\subsection{PCA of Sediment and Water Samples}

Principal components analysis (PCA) is robust with respect to multivariate data normality and as it is an exploratory technique it does not involve statistical significance testing. PCA is a statistical method used to decide components that are linear combinations of the original variables. The central idea of the PCA is to reduce the dimensionality of a data set consisting of a large number of interrelated variables, while retaining as much as possible of the variation present in the data set. The Principal Component Analysis was employed to infer the hypothetical source of trace metals (natural or anthropogenic). The components of the PCA were rotated by a varimax rotation. The PCA is a standard approach to explore the variability in multivariate data by converting the observations of possibly correlated variables into a set of linearly independent variables, namely Principal Components (PCs) and has been frequently used to investigate environmental pollution with respect to different factors, including major pollutants, influential factors, or possible sources (Nobi et al., 2010). A Varimax rotation 
was applied to aid interpretation of the results, this works by loading variables more strongly on fewer factors, but should only be applied where correlations between the factors are not expected. In PCA, the first PC, is the linear combination of the variables with maximal variance and represents the largest variability of the original data set. The second component is the linear combination with the next largest variability that is orthogonal to the first components and so on (Garizi et al., 2011).

\subsection{Statistical Analysis}

The data obtained from analytical methods were treated statistically using SPSS software (version 20.0 for windows). Descriptive data analysis was performed, including the calculation of mean, SD, maximum, minimum. Pearson correlation matrix was performed to identify the relationship between the trace metals.

\section{RESULTS}

\subsection{Trace Elements in Sediment Samples}

The concentrations of tracemetals in the deep sediment sections of the Dam given in Table 4. Showed wide variations among the sampling points. The trace metals concentration in the sediment samples ranged from $\left(\mathrm{mg} \mathrm{kg}^{-1}\right)$ : Copper- 61.5 to113.7, Chromium- 138.4 to 177.5 , Cobalt- 33.2 to 42.7 , Cadmium 1.0 to 2.1 , Lead 57.9 to 103.4 , Nickel 36.1 to 56.6 , Zinc- 51.2 to 102.1 , Manganese 610.8 to 1301.7 , Iron $2.5-2.9 \%$. Iron was the major element in the sediment followed by Manganese and the concentration of other trace elementsare in the order of $\mathrm{Fe}>\mathrm{Mn}>\mathrm{Cr}>\mathrm{Cu}>\mathrm{Pb}>\mathrm{Zn}>\mathrm{Ni}>\mathrm{Co}>\mathrm{Cd}$. The concentrations for metallic trace elements bear the positive correlation coefficients among themselves.

Sartandel et al. (2009) have reported that the trace elements lead and chromium in the top sediment $(0-10 \mathrm{~cm})$ from Peddagattu ranged from $120 \mathrm{mg} \mathrm{kg}^{-1}$ and $211 \mathrm{mg} \mathrm{kg}^{-1}$ and the concentration gradient of lead and chromium suggested a change in geochemical characteristics of sediments and influence of fine particulates input through river in this area (Sartandel et al., 2009). Similarly Krishna et al. (2011) has reported the chromium values in the range of 15.8 to $107.8 \mathrm{mg} \mathrm{kg}^{-1}$ (Krishna et al., 2011) in the sediment samples of Wailpalli Watershed, Nalgonda District nearer to the Nagarjuna Sagar dam.

\subsection{Trace Metals in the Water Samples}

The trace metals concentrations in the surface water samples of Nagarjuna Sagar Dam given in Table $\mathbf{5}$ are the mean value of the ten sampling points showed the values in $\left(\mu \mathrm{g} \mathrm{L}^{-1}\right)$ copper- 24.2 to 47.5 , chromium -4.4 to
8.2, cadmium-0.1 to 0.3 , lead-2.1 to 3.8 , Nickel-5.9 to 9.7, Zinc-4.6 to 9.7 , Manganese-10.8 to 13.2 , Iron- 52.9 to 157.2 , cobalt and arsenic were in BDL.The average concentrations of the trace elements in the Dam water was within the permissible limits of the Bureau of Indian Standards (BIS 10500: 1991). In addition, the results were comparable to the previous reports clearly demonstrated that the Dam water has not been polluted with trace metals. Contaminants enter the reserviours through mainly two pathways. These are firstly point sources that are identifiable sources such as municipal, industrial wastewater effluents. The second patway is called diffuse sources which are closely related to meteorological factors. Major diffuse sources include: Surface run-off, erosion, atmospheric deposition.

The trace elements contents in river and reservoir sediments of the various locations around the world are discussed in the Table 6. (Förstner, 1981) has described the world average metal concentration in the sediment samples. The earth's crust content is used as background for different reliable sediment quality indices where no background or reference value is available. In our study, as described earlier four reliable indices such as Enrichment factor, Contamination factor, Geoaccumulation Index and Pollution Load Index were applied to estimate metal pollution and the results comparison are discussed below.

\subsection{Enrichment Factor (EF) for the Sediment}

The Enrichment Factor (EF) is a convenient measure of geochemical trends and is used for making comparisons between areas. The EF values were calculated from the mean concentrations of the trace metals within the sampling points of the study area. The unpolluted or background point sampling point was considered to be the control point. The normalizing element used in this study was iron $(\mathrm{Fe})$ because of its occurrence of low variability. The Enrichment Factor (EF) for the deep bottom Damsediments was determined and interpreted as suggested by Birch 2003 and tabulated in Table 7.

A value of unity denotes neither enrichment nor depletion relative to the Earth's crust (Hasan et al., 2013). From Table 7 it is evident that Cadmium and nickel has shown no enrichment $(\mathrm{EF}<1)$ in all ten sampling locations indicated that these metals were derived from the natural sources, such as underlying geological material. The metals copper, chromium, cobalt are in minor enrichment $(1 \leq \mathrm{EF}<3)$ in all the sampling points whereas lead in the sampling points SPS1 to SPS3 is moderately severe enrichment while the other sampling (SPS4 to SPS10) locations showed moderate enrichment. 
Kantha Deivi Arunachalam et al. / American Journal of Environmental Science 10 (2): 102-122, 2014

Table 4. Concentration and descriptive statistics of trace elements in fresh water dam sediments

\begin{tabular}{|c|c|c|c|c|c|c|c|c|c|c|}
\hline \multirow[b]{2}{*}{$\begin{array}{l}\text { Sample } \\
\text { code }\end{array}$} & \multicolumn{10}{|c|}{ Concentration of trace elements in the deep sediment $\left(\mathrm{mg} \mathrm{kg}^{-1}\right)$} \\
\hline & $\begin{array}{l}\text { Copper } \\
(\mathrm{Cu})\end{array}$ & $\begin{array}{l}\text { Chromium } \\
\text { (Cr) }\end{array}$ & $\begin{array}{l}\text { Cobalt } \\
\text { (Co) }\end{array}$ & $\begin{array}{l}\text { Cadmium } \\
\text { (Cd) }\end{array}$ & $\begin{array}{l}\text { Lead } \\
(\mathrm{Pb})\end{array}$ & $\begin{array}{l}\text { Nickel } \\
(\mathrm{Ni})\end{array}$ & $\begin{array}{l}\text { Zinc } \\
(\mathrm{Zn})\end{array}$ & $\begin{array}{l}\text { Manganese } \\
(\mathrm{Mn})\end{array}$ & $\begin{array}{l}\text { Iron } \\
(\mathrm{Fe})\end{array}$ & $\begin{array}{l}\text { Arsenic } \\
\text { (As) }\end{array}$ \\
\hline SPS1 & 100.800 & 177.000 & 33.90 & 1.00 & 103.4 & 50.40 & 96.400 & 1187.90 & 29000.200 & BDL \\
\hline SPS2 & 75.400 & 169.800 & 40.70 & 2.00 & 96.9 & 56.60 & 98.200 & 1013.30 & 28360.900 & $\mathrm{BDL}$ \\
\hline SPS3 & 76.500 & 174.500 & 41.80 & 1.00 & 102.4 & 49.90 & 102.100 & 1301.70 & 28355.700 & BDL \\
\hline SPS4 & 65.400 & 138.400 & 33.20 & 2.00 & 82.1 & 49.90 & 88.100 & 1161.20 & 28406.400 & BDL \\
\hline SPS5 & 103.700 & 174.800 & 41.90 & 2.10 & 57.9 & 51.80 & 66.800 & 782.50 & 28902.400 & BDL \\
\hline SPS6 & 92.400 & 177.500 & 34.00 & 2.10 & 67.3 & 53.10 & 63.500 & 1059.10 & 29075.400 & $\mathrm{BDL}$ \\
\hline SPS7 & 66.200 & 140.800 & 42.20 & 2.10 & 72.8 & 43.40 & 54.200 & 919.30 & 29185.900 & BDL \\
\hline SPS8 & 99.400 & 142.400 & 42.70 & 2.10 & 69.6 & 43.90 & 58.200 & 610.80 & 28994.800 & BDL \\
\hline SPS9 & 61.500 & 139.500 & 33.40 & 2.10 & 59.4 & 36.60 & 51.200 & 741.20 & 28813.800 & BDL \\
\hline SPS10 & 68.200 & 146.800 & 35.30 & 2.10 & 65.0 & 36.10 & 65.500 & 628.60 & 25954.100 & BDL \\
\hline Arithme & 81.000 & 158.200 & 37.90 & 1.90 & 77.7 & 47.20 & 74.400 & 940.60 & 28505.000 & - \\
\hline Geomentric mean & 79.500 & 157.300 & 37.70 & 1.80 & 76.0 & 46.70 & 72.100 & 911.20 & 28490.100 & - \\
\hline SD & 16.400 & 17.700 & 4.20 & 0.50 & 17.5 & 6.90 & 19.600 & 242.90 & 947.900 & - \\
\hline Minimum & 61.500 & 138.400 & 33.20 & 1.00 & 57.9 & 36.10 & 51.200 & 610.80 & 25954.100 & - \\
\hline Maximum & 103.700 & 177.500 & 42.70 & 2.10 & 103.4 & 56.60 & 102.100 & 1301.70 & 29185.900 & - \\
\hline BDL Limits & 0.008 & 0.075 & 0.01 & 0.01 & 0.1 & 0.01 & 0.042 & 0.01 & 0.015 & 0.005 \\
\hline
\end{tabular}

*BDL- Below Detection Limit

Table 5. Concentration and descriptive statistics of trace elements in dam surface water

\section{Concentration of trace elements in dam surface water $(\mathrm{mg} / \mathrm{L})$}

\begin{tabular}{|c|c|c|c|c|c|c|c|c|c|c|}
\hline $\begin{array}{l}\text { Sample } \\
\text { code }\end{array}$ & $\begin{array}{l}\text { Copper } \\
(\mathrm{Cu})\end{array}$ & $\begin{array}{l}\text { Chromium } \\
\text { (Cr) }\end{array}$ & $\begin{array}{l}\text { Cobalt } \\
\text { (Co) }\end{array}$ & $\begin{array}{l}\text { Cadmium } \\
\text { (Cd) }\end{array}$ & $\begin{array}{l}\text { Lead } \\
(\mathrm{Pb})\end{array}$ & $\begin{array}{l}\text { Nickel } \\
(\mathrm{Ni})\end{array}$ & $\begin{array}{l}\text { Zinc } \\
(\mathrm{Zn})\end{array}$ & $\begin{array}{l}\text { Manganese } \\
(\mathrm{Mn})\end{array}$ & $\begin{array}{l}\text { Iron } \\
(\mathrm{Fe})\end{array}$ & $\begin{array}{l}\text { Arsenic } \\
\text { (As) }\end{array}$ \\
\hline$\overline{\text { SPW1 }}$ & 28.400 & 8.200 & BDL & 0.30 & 2.4 & 9.00 & 9.700 & 12.50 & 136.300 & BDL \\
\hline SPW2 & 29.400 & 6.500 & BDL & 0.20 & 2.4 & 8.80 & 8.600 & 12.70 & 123.500 & BDL \\
\hline SPW3 & 43.200 & 7.200 & BDL & 0.10 & 2.6 & 6.80 & 7.700 & 13.20 & 114.300 & BDL \\
\hline SPW4 & 43.700 & 5.600 & BDL & 0.30 & 2.5 & 8.10 & 6.300 & 11.20 & 52.900 & BDL \\
\hline SPW5 & 31.400 & 4.600 & $\mathrm{BDL}$ & 0.20 & 2.1 & 7.20 & 9.600 & 12.50 & 148.000 & BDL \\
\hline SPW6 & 38.000 & 4.400 & BDL & 0.30 & 2.8 & 7.80 & 8.600 & 11.60 & 146.500 & BDL \\
\hline SPW7 & 24.200 & 7.400 & BDL & 0.10 & 3.8 & 8.50 & 4.600 & 12.30 & 152.000 & BDL \\
\hline SPW8 & 33.500 & 5.800 & BDL & 0.30 & 3.7 & 6.30 & 6.900 & 10.80 & 155.800 & BDL \\
\hline SPW9 & 47.500 & 7.900 & BDL & 0.30 & 3.3 & 9.70 & 7.900 & 12.30 & 134.200 & BDL \\
\hline SPW10 & 36.100 & 6.400 & BDL & 0.20 & 2.4 & 5.90 & 6.400 & 11.90 & 157.200 & BDL \\
\hline Arithmetic mean & 35.500 & 6.400 & - & 0.20 & 2.8 & 7.80 & 7.600 & 12.10 & 132.100 & - \\
\hline Geomentric Mean & 34.800 & 6.300 & - & 0.20 & 2.7 & 7.70 & 7.500 & 12.10 & 127.100 & - \\
\hline SD & 7.600 & 1.300 & - & 0.10 & 0.6 & 1.20 & 1.600 & 0.70 & 31.200 & - \\
\hline Minimum & 24.200 & 4.400 & - & 0.10 & 2.1 & 5.90 & 4.600 & 10.80 & 52.900 & - \\
\hline Maximum & 47.500 & 8.200 & - & 0.30 & 3.8 & 9.70 & 9.700 & 13.20 & 157.200 & - \\
\hline BDL Limits & 0.008 & 0.075 & 0.01 & 0.01 & 0.1 & 0.01 & 0.042 & 0.01 & 0.015 & 0.005 \\
\hline
\end{tabular}

Table 6. Comparison of Trace element concentration in sediment samples of other rivers and reservoirs

\begin{tabular}{|c|c|c|c|c|c|c|c|c|c|}
\hline Name of reservoir & $\mathrm{Cu}$ & $\mathrm{Cr}$ & $\mathrm{Cd}$ & $\mathrm{Pb}$ & $\mathrm{Ni}$ & $\mathrm{Zn}$ & $\mathrm{Mn}$ & $\mathrm{Fe}$ & References \\
\hline Nagarjuna Sagar Dam & $61.5-103.7$ & $138.4-177.5$ & $1.1-2.1$ & $57.9-103.4$ & $36.1-56.6$ & $51.2-102.1$ & $610.8-1301.7$ & $25954-29185$ & Present study \\
\hline $\begin{array}{l}\text { Manwan dam, } \\
\text { China }(\mu \mathrm{g} / \mathrm{g})\end{array}$ & $15.85-56.32$ & $28.29-89.85$ & $0.24-2.5$ & $17.03-92.20$ & - & $45.32-259.84$ & $246.58-769.06$ & $\begin{array}{l}19,133- \\
37,936\end{array}$ & (Wang et al., 2012) \\
\hline $\begin{array}{l}\text { Rybnik Resevoir, Polland } \\
(\mu \mathrm{g} / \mathrm{g})\end{array}$ & $16-1116$ & $14.27-739.11$ & $2.40-85.06$ & $11-315$ & $3-183$ & $50-2441$ & $246-4215$ & $3982-98510$ & $\begin{array}{l}\text { (Loska and } \\
\text { Wiechuła, 2003) }\end{array}$ \\
\hline $\begin{array}{l}\text { Wadi Al-Arab dam, } \\
\text { Jordan (mglg) }\end{array}$ & $0.022-0.186$ & - & $0.0055-0.0125$ & - & - & $0.172-0.964$ & $0.201-0.806$ & $7.77-15.75$ & $\begin{array}{l}\text { (Ghrefat and } \\
\text { Yusuf, 2006) }\end{array}$ \\
\hline $\begin{array}{l}\text { Ataturk dam, } \\
\text { Turkey }(\mathrm{mg} / \mathrm{kg})\end{array}$ & 14.57 & - & - & - & 43.69 & 60.78 & 73.60 & 12587 & $\begin{array}{l}\text { Karadede and } \\
\text { Unlu (2000) }\end{array}$ \\
\hline $\begin{array}{l}\text { Veeranam lake sediments, } \\
\text { India }(\mathrm{mg} / \mathrm{kg})\end{array}$ & $65.44-125.64$ & $39.84-150.41$ & $0.20-3.90$ & $20.11-41.0$ & $34.32-95.60$ & $68.8-598.8$ & - & - & (Suresh et al., 2012) \\
\hline $\begin{array}{l}\text { Bed sediments of Krishna } \\
\text { River Basin }(\mu \mathrm{g} / \mathrm{g})\end{array}$ & 35 & 82 & - & - & 32 & 26 & 906 & 25000 & (Ramesh et al., 1990) \\
\hline $\begin{array}{l}\text { Krishna mainstream } \\
\text { sediments }(\mathrm{mg} / \mathrm{kg})\end{array}$ & $206-291$ & $138-206$ & - & - & $88-100$ & $164-223$ & $0.17-0.22 \%$ & $13-17.4$ & $\begin{array}{l}\text { (Das and } \\
\text { Krishnaswami (2007) }\end{array}$ \\
\hline World average $(\mathrm{mg} / \mathrm{kg})$ & $20-90$ & $20-190$ & $0.1-1.5$ & $10-100$ & $30-250$ & $50-250$ & - & - & (Förstner, 1981) \\
\hline
\end{tabular}


Where as, Zinc showed no enrichment $(\mathrm{EF}<1)$ in the sampling points SPS5 to SPS9 and showed minor enrichment in the sampling points SP1 to SP4 and SP 10.The EF value of nearly 1 suggests that a given metal may originate entirely from natural sources, such as crustal materials or natural weathering processes (Tang et al., 2013). When the EF value showed minor enrichment significant portion of the metal originated from anthropogenic processes only. So our study results for lead showed that lead is the only major metal which might have originated from the anthropogenic process. Anzali international wetland located in southwestern Caspian Seacoast is one of the most important wetlands of Iran have showed EFs greater than 10 for Cd. (Jamshidi-Zanjani and Saeedi, 2013).

\subsection{Contamination Factor $\mathrm{C}_{\mathrm{f}}^{\mathrm{i}}$ and Modified Degree of Contamination $\left(\mathrm{mC}_{\mathrm{d}}\right)$ for Sediment}

The contamination factor and the degree of contamination calculated for the fresh water Dam sediment samples are tabulated in Table 8. The results of the modified Degree of Contamination clearly showed that Nickel and Zinc has the low Degree of Contamination, whereas $\mathrm{Cu}, \mathrm{Cr}$, Co were in Moderate Degree of Contamination in all the sampling locations. Lead and Cadmium showed high degree of Contamination to very high degree of contamination as classified by Hakanson (1980). Abrahim and Parker (2008) has reported that modified degree value of cadmium indicates a moderate to high degree of fine fraction sediment contamination in Tamaki Estuary.

\subsection{Classification of Geo-Accumulation Index for Dam Sediment}

The Geo accumulation indexes for the Dam sediment samples were calculated using Equation 4 are listed in Table 9. The $I_{\text {geo }}$ values $<1$ corresponds to Not Contaminated to moderately contaminated were observed for nickel and zinc. The elements chromium and cobalt has $\mathrm{I}_{\text {geo }}$ values $<2$ which is moderately contaminated whereas lead showed highly contaminated for sampling locations SPS1 to SPS3 with $\mathrm{I}_{\text {geo }}$ values $<4, \mathrm{I}_{\text {geo }}$ values $<3$ was shown for SPS4, SPS6, SPS7, SPS8 and SPS10 while SPS5 and SPS9 showed $\mathrm{I}_{\mathrm{geo}}$ values $<2$.

Cadmium pollution observed in the Dam sediment is due to anthropogenic sources including fertilizers and pesticides used in the agricultural fields around the sampling points SPS8 to SPS10 in Lambhapur where agricultural activities are done by the tribal people. Similarly Cevik et al. (2009) had assessed the Cadmium as the only pollution element in the surface sediments of Seyhan dam where the anthropogenic sources were via fertilizers and pesticides. He has also pointed out that the usage volume of fertilizers is higher in the region than the national average (Cevik et al., 2009). According to the geoaccumulation index categorized by Magesh et al. (2011) in revealed that the sediments of Tamiraparani Estuary, southeast coast of India is extremely contaminated by $\mathrm{Cd}$ (Magesh et al., 2011). Similarly Hindon River sediments have also been reported for strong cadmium contamination range (Chabukdhara and Nema, 2012).

\subsection{Pollution Load Index (PLI)}

The Pollution load index is an integrated index which combines all trace metals to one index which allows comparison of pollution status of various sites so the priority contamination sites can be identified for remediation. Table $\mathbf{1 0}$ clearly shows the analyzed Damsediment samples were not contaminated for Nickel and Zinc while $\mathrm{Co}, \mathrm{Cd}, \mathrm{Cu}, \mathrm{Cr}, \mathrm{Pb}$ contamination was observed. $\mathrm{I}_{\text {geo }}$ and $\mathrm{EF}$ depend on the background data used, grain size and bonding forms of metals. The PLI calculated for every sampling point exceeds the background pollution and pointed to the anthropogenic load at each studied site. It can be assumed from our results that Lead and cadmium are the only major elements originated from the anthropogenic where as the PLI of the other elements showed that the area may be polluted but it is in the range of non polluted site.

Table 7. Trace metals enrichment factor for deep bottom dam sediments

\begin{tabular}{llllcccc}
\hline $\begin{array}{l}\text { Sample } \\
\text { code }\end{array}$ & $\begin{array}{l}\text { Copper } \\
(\mathrm{Cu})\end{array}$ & $\begin{array}{l}\text { Chromium } \\
(\mathrm{Cr})\end{array}$ & $\begin{array}{l}\text { Cobalt } \\
(\mathrm{Co})\end{array}$ & $\begin{array}{l}\text { Cadmium } \\
(\mathrm{Cd})\end{array}$ & $\begin{array}{l}\text { Lead } \\
(\mathrm{Pb})\end{array}$ & $\begin{array}{l}\text { Nickel } \\
(\mathrm{Ni})\end{array}$ & $\begin{array}{l}\text { Zinc } \\
(\mathrm{Zn})\end{array}$ \\
\hline SPS1 & 2.03 & 2.03 & 1.95 & 0.17 & 5.94 & 0.61 & 1.39 \\
SPS2 & 1.55 & 1.99 & 2.39 & 0.36 & 5.69 & 0.70 & 1.44 \\
SPS3 & 1.58 & 2.05 & 2.45 & 0.18 & 6.01 & 0.62 & 1.50 \\
SPS4 & 1.35 & 1.62 & 1.95 & 0.36 & 4.81 & 0.62 & 1.29 \\
SPS5 & 2.10 & 2.01 & 2.41 & 0.37 & 3.34 & 0.63 & 0.96 \\
SPS6 & 1.86 & 2.03 & 1.95 & 0.36 & 3.85 & 0.64 & 0.91 \\
SPS7 & 1.33 & 1.61 & 2.41 & 0.36 & 4.15 & 0.52 & 0.77 \\
SPS8 & 2.00 & 1.64 & 2.45 & 0.37 & 4.00 & 0.53 & 0.84 \\
SPS9 & 1.25 & 1.61 & 1.93 & 0.37 & 3.43 & 0.45 & 0.74 \\
SPS10 & 1.54 & 1.88 & 2.26 & 0.41 & 4.17 & 0.49 & 1.05 \\
\hline
\end{tabular}


Table 8. Contamination factor and modified degree of contamination for dam sediment

\begin{tabular}{|c|c|c|c|c|c|c|c|}
\hline \multirow[b]{2}{*}{$\begin{array}{l}\text { Sample } \\
\text { code }\end{array}$} & \multicolumn{6}{|c|}{ Contamination factor $\mathrm{C}_{\mathrm{f}}^{\mathrm{i}}$ for fresh water dam sediments } & \multirow[b]{2}{*}{$\begin{array}{l}\text { Zinc } \\
(\mathrm{Zn})\end{array}$} \\
\hline & $\begin{array}{l}\text { Copper } \\
(\mathrm{Cu})\end{array}$ & $\begin{array}{l}\text { Chromium } \\
\text { (Cr) }\end{array}$ & $\begin{array}{l}\text { Cobalt } \\
\text { (Co) }\end{array}$ & $\begin{array}{l}\text { Cadmium } \\
(\mathrm{Cd})\end{array}$ & $\begin{array}{l}\text { Lead } \\
(\mathrm{Pb})\end{array}$ & $\begin{array}{l}\text { Nickel } \\
(\mathrm{Ni})\end{array}$ & \\
\hline$\overline{\text { SPS1 }}$ & 1.77 & 1.77 & 1.78 & 5.0 & 5.17 & 0.74 & 1.01 \\
\hline SPS2 & 1.32 & 1.70 & 2.14 & 10.0 & 4.85 & 0.83 & 1.03 \\
\hline SPS3 & 1.34 & 1.75 & 2.20 & 5.0 & 5.12 & 0.73 & 1.07 \\
\hline SPS4 & 1.15 & 1.38 & 1.75 & 10.0 & 4.11 & 0.73 & 0.93 \\
\hline SPS5 & 1.82 & 1.75 & 2.21 & 10.5 & 2.90 & 0.76 & 0.70 \\
\hline SPS6 & 1.62 & 1.78 & 1.79 & 10.5 & 3.37 & 0.78 & 0.67 \\
\hline SPS7 & 1.16 & 1.41 & 2.22 & 10.5 & 3.64 & 0.64 & 0.57 \\
\hline SPS8 & 1.74 & 1.42 & 2.25 & 10.5 & 3.48 & 0.65 & 0.61 \\
\hline SPS9 & 1.08 & 1.40 & 1.76 & 10.5 & 2.97 & 0.54 & 0.54 \\
\hline SPS10 & 1.20 & 1.47 & 1.86 & 10.5 & 3.25 & 0.53 & 0.69 \\
\hline $\begin{array}{l}\text { Modified degree of } \\
\text { contamination }\left(\mathrm{mC}_{\mathrm{d}}\right)\end{array}$ & 2.57 & 4.51 & 2.85 & 13.28 & 5.54 & 1.77 & 1.11 \\
\hline $\begin{array}{l}\text { Sample } \\
\text { code }\end{array}$ & $\begin{array}{l}\text { Copper } \\
(\mathrm{Cu})\end{array}$ & $\begin{array}{l}\text { Chromium } \\
\text { (Cr) }\end{array}$ & $\begin{array}{l}\text { Cobalt } \\
\text { (Co) }\end{array}$ & $\begin{array}{l}\text { Cadmium } \\
\text { (Cd) }\end{array}$ & $\begin{array}{l}\text { Lead } \\
(\mathrm{Pb})\end{array}$ & $\begin{array}{l}\text { Nickel } \\
\text { (Ni) }\end{array}$ & $\begin{array}{l}\text { Zinc } \\
\text { (Zn) }\end{array}$ \\
\hline SPS1 & 1.18 & 1.31 & 1.19 & 3.33 & 3.45 & 0.49 & 0.68 \\
\hline SPS2 & 0.88 & 1.26 & 1.43 & 6.67 & 3.23 & 0.55 & 0.69 \\
\hline SPS3 & 0.89 & 1.29 & 1.47 & 3.33 & 3.41 & 0.49 & 0.72 \\
\hline SPS4 & 0.76 & 1.03 & 1.16 & 6.67 & 2.74 & 0.49 & 0.62 \\
\hline SPS5 & 1.21 & 1.29 & 1.47 & 7.00 & 1.93 & 0.51 & 0.47 \\
\hline SPS6 & 1.08 & 1.31 & 1.19 & 7.00 & 2.24 & 0.52 & 0.45 \\
\hline SPS7 & 0.77 & 1.04 & 1.48 & 7.00 & 2.43 & 0.43 & 0.38 \\
\hline SPS8 & 1.16 & 1.05 & 1.50 & 7.00 & 2.32 & 0.43 & 0.41 \\
\hline SPS9 & 0.72 & 1.03 & 1.17 & 7.00 & 1.98 & 0.36 & 0.36 \\
\hline SPS10 & 0.80 & 1.09 & 1.24 & 7.00 & 2.17 & 0.35 & 0.46 \\
\hline
\end{tabular}

Table 10. Pollution load index and the status of trace metal pollution in dam sediments

\begin{tabular}{lll}
\hline Trace metals & Pollution load index & Status \\
\hline Copper $(\mathrm{Cu})$ & 1.39 & Polluted \\
Chromium $(\mathrm{Cr})$ & 1.57 & Polluted \\
Cobalt $(\mathrm{Co})$ & 1.98 & Polluted \\
Cadmium $(\mathrm{Cd})$ & 8.96 & Polluted \\
Lead $(\mathrm{Pb})$ & 3.79 & Polluted \\
Nickel $(\mathrm{Ni})$ & 0.69 & Not polluted \\
Zinc $(\mathrm{Zn})$ & 0.76 & Not polluted \\
\hline
\end{tabular}

The PLI values for the studied Dam sediments ranged from 0.69 to 8.96 with an average of 2.73. Suresh et al. (2012) has reported that Veeranam lake sediments in India the PLI values are ranged from 1.18 to 4.09 with an average of 2.03. Qiao et al. (2013) has reported that Shantou Bay was slightly impacted by metal pollutants with PLI values ranging from 0.97 to 1.79 and a zonal PLI value of 1.22 .

\subsection{Spatial Analysis of Trace Metals in Dam}

A GIS-based chemometric approach has proven to be useful in determining the spatial distribution patterns of trace metals in sediments and water samples to identify impacts of pollution at the sampling locations. The Spatial analysis of the sediment and the water samples are shown in the Fig. 2 and 3. By visualizing the degree of trace element contamination in sediments and water by spatial interpolation exposes the pollution status of the fresh water aquatic ecosystem. The spatial association and scaling are two different aspects of local structures and surfaces. Both should be taken into account in data interpolation and surface mapping of geochemical variables.

From Fig. 2 the spatial distribution pattern of trace metals in deep bottom sediments of Nagarjuna Sagar dam, it is observed that copper (Fig. 2A), cobalt (Fig. 2C) and Iron (Fig. 2I) follow similar pattern of distribution; it is further confirmed by the principle component analysis (Table 13 and Fig. 4). Chromium (Fig. 2B) and Nickel (Fig. 2F) follow the similar pattern of distribution, whereas Lead (Fig. 2E), Zinc (Fig. 2G) and Manganese (Fig. 2H) follow the quite different pattern from above metals. The trace metal Cadmium (Fig. 2D) does not follow any trend as compared with any other metal, since the cadmium is considered to have an anthropogenic origin of pollution from the fertilizers and pesticides used in agricultural activities around the sampling points. The 
differential distribution of trace elements may indicate their different sources of origin and the controlling mechanism of distribution patterns, which can be clearly understood from the principle component analysis.

From Fig. 3 the spatial distribution of trace metal in surface water samples of the reservoir showed the different distribution pattern among the analyzed metals. From the results it is observed that lead (Fig. 3D), copper (Fig. 3A) and Chromium (Fig. 3B), followed the similar geographical trends. The metal zinc (Fig. 3F), Nickel (Fig. 3E) andiron (Fig. 3H), follow different spatial distribution. The spatial surveys of trace metals in water samples is the key step in understanding the contamination in the freshwater aquatic ecosystem. The spatial trends of contaminated major elements like cadmium and lead showed similar trend of the spatial distribution of sediment and water samples from the reservoir.
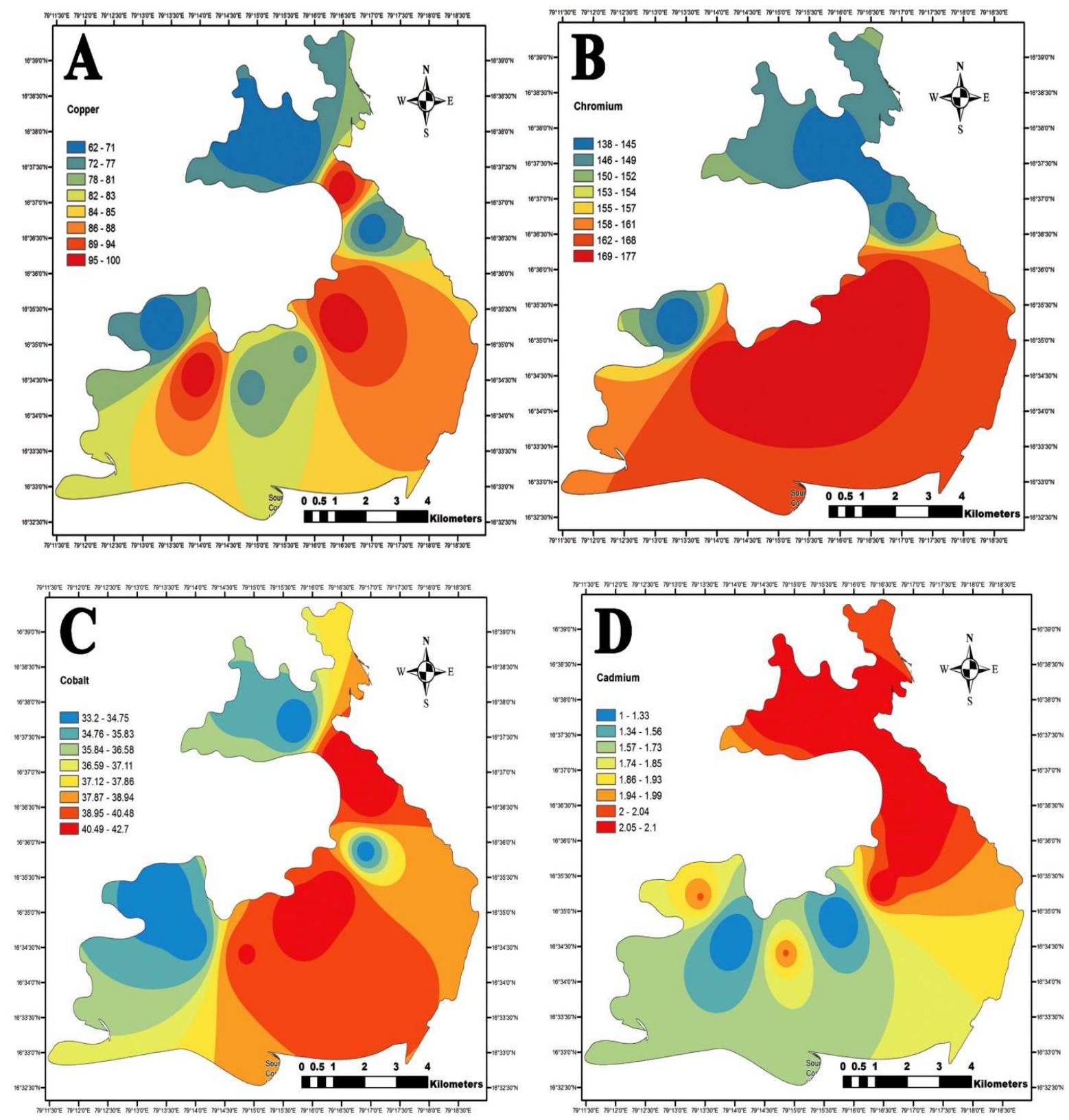
Kantha Deivi Arunachalam et al. / American Journal of Environmental Science 10 (2): 102-122, 2014
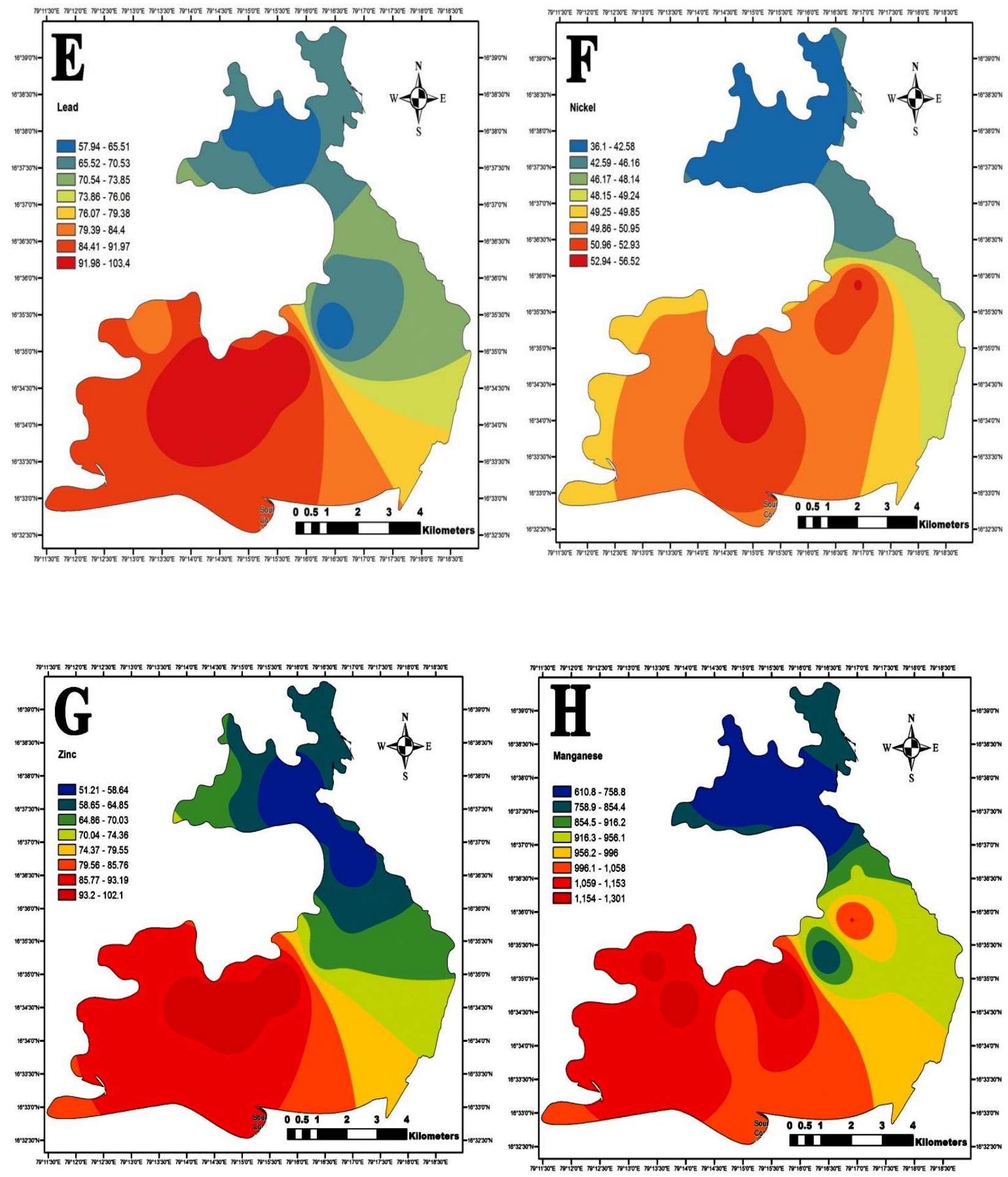


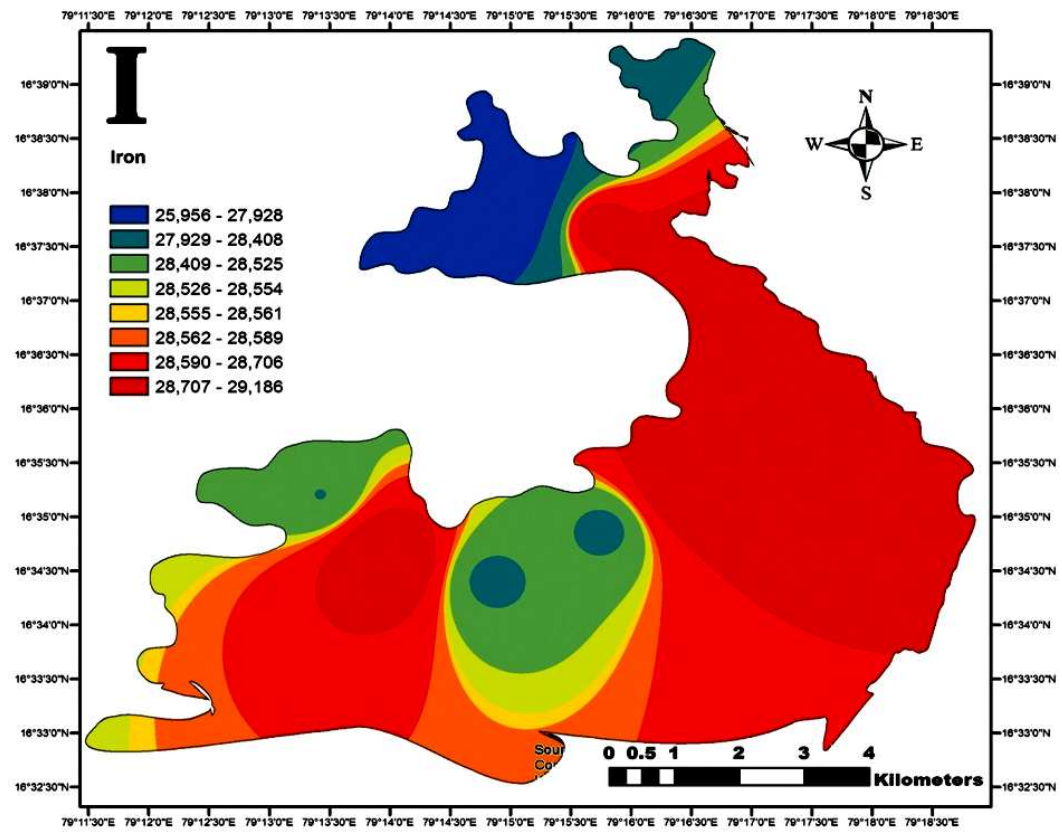

Fig 2. Spatial distribution pattern of trace metals in bottom sediments of Nagarjuna Sagar Dam (A) Copper (B) chromium (C) Cobalt (D) Cadmium (E) Lead (F) Nickel (G) Zinc (H) Manganese (I) Iron

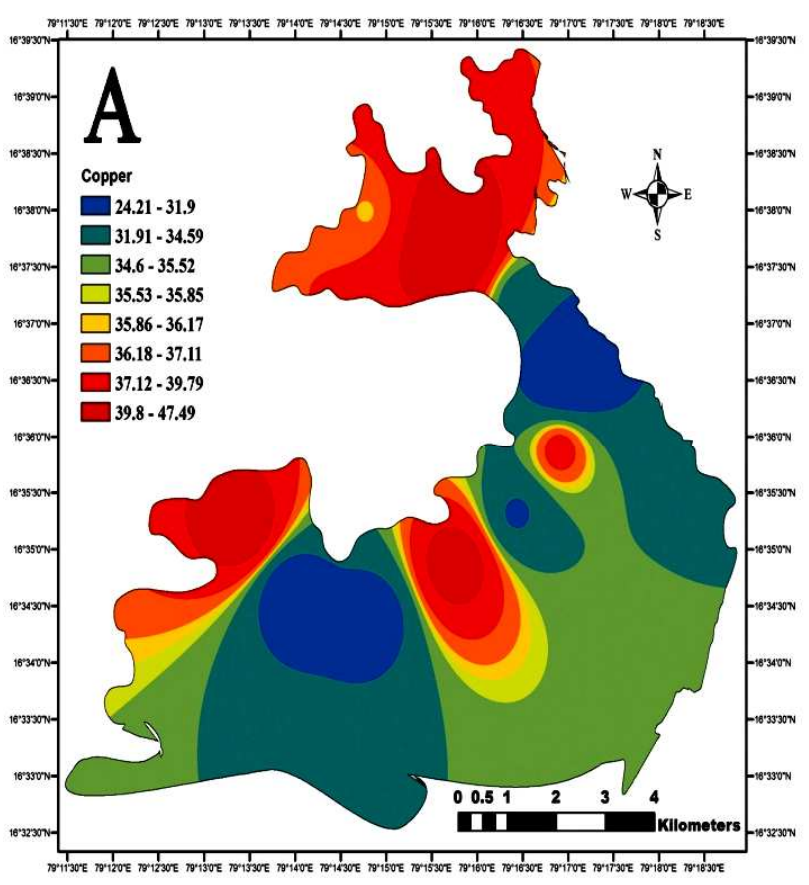

Science Publications

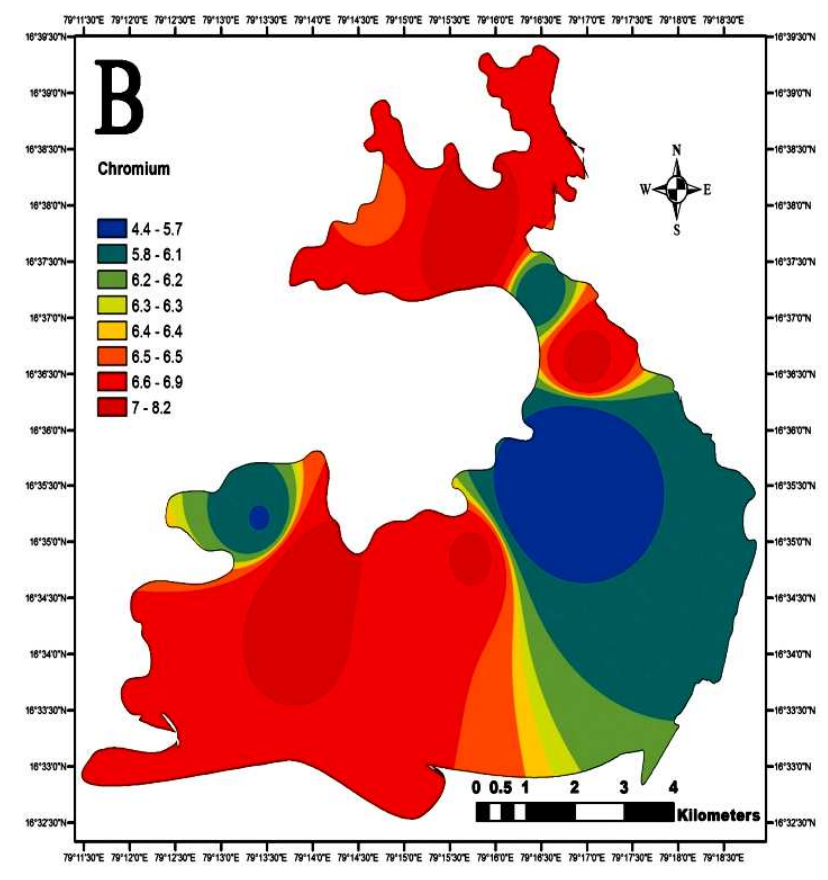

113 
Kantha Deivi Arunachalam et al. / American Journal of Environmental Science 10 (2): 102-122, 2014
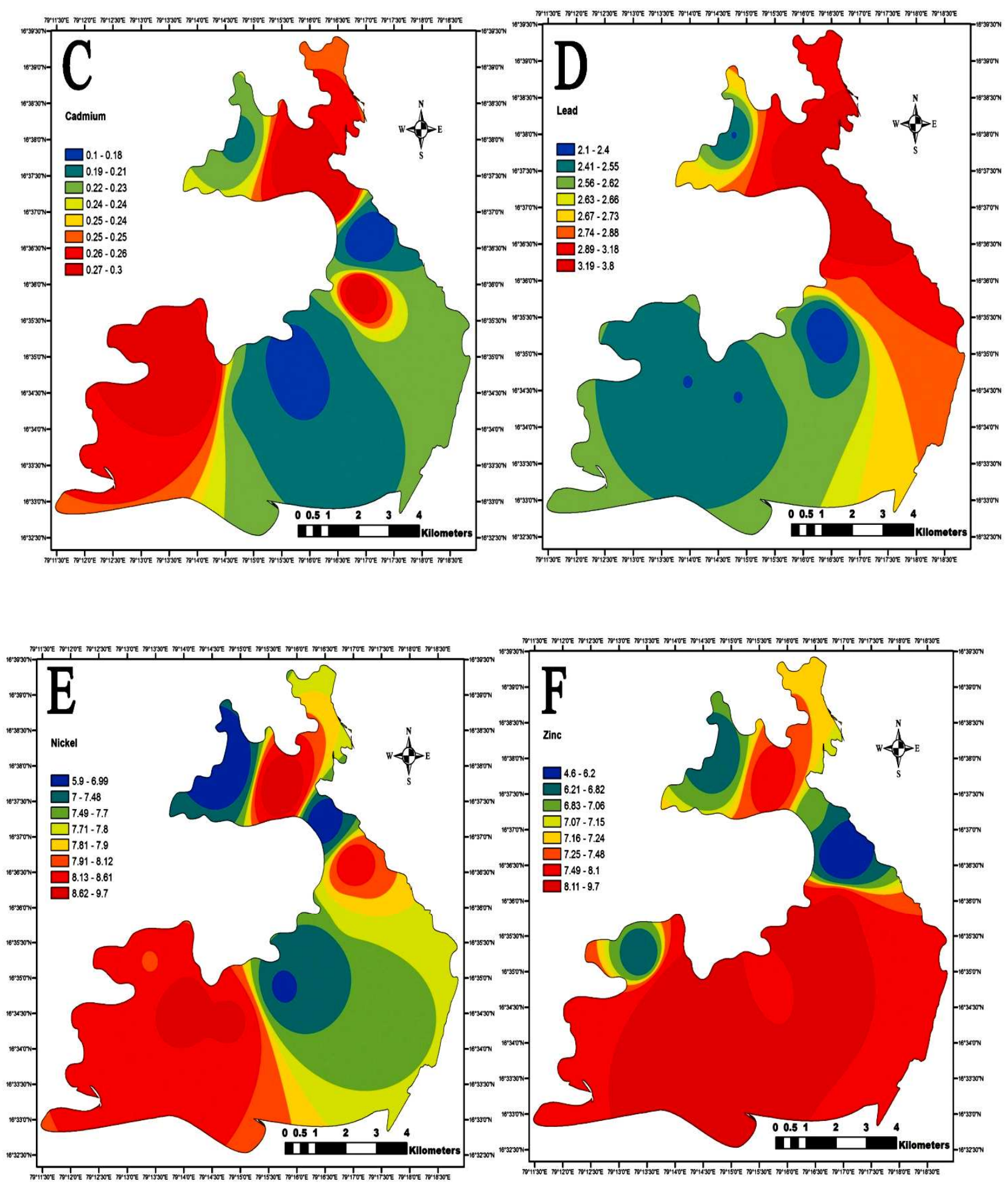

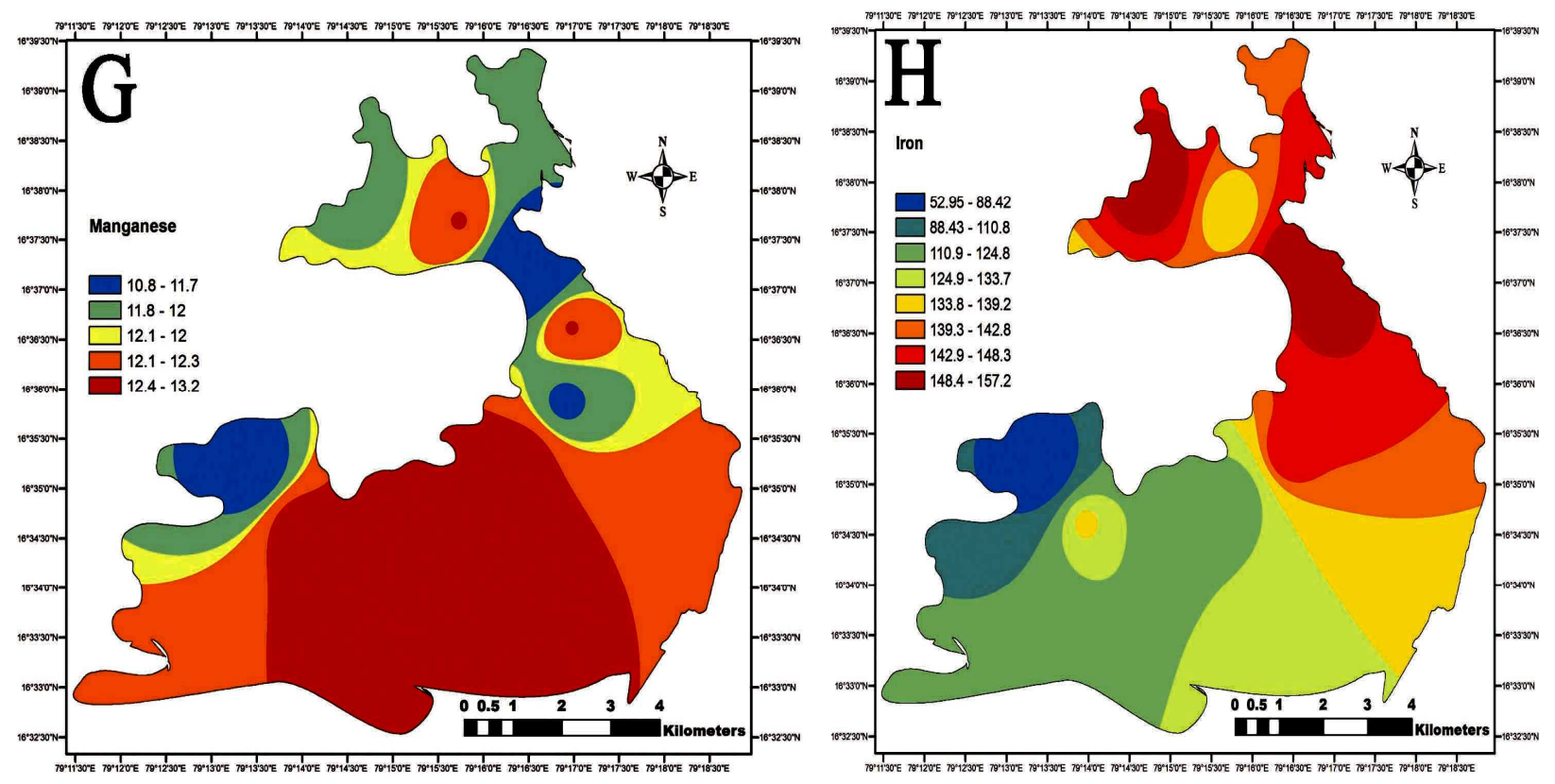

Fig. 3. Spatial distribution of trace metal in surface water samples of Nagarjuna Sagar Dam (A) Copper (B) Chromium (C) Cadmium (D) Lead (E) Nickel (F) Zinc (G) Manganese (H) Iron

\subsection{Pearson Correlation Analysis}

Interrelation between metals can provide information on sources of contamination and heavy metal pathways The Pearson Correlation matrixes of trace metals in sediments presented in Table 11. established a positive correlation for few metals and the correlation is significant at $\mathrm{p}<0.01$ level for zinc and lead $(\mathrm{r}=0.907)$. Similarly manganese is positively Correlated at $\mathrm{p}<0.01$ for lead $(r=0.784)$ and $\operatorname{zinc}(r=0.775)$. Chromium is positively correlated to nickel $(\mathrm{r}=0.719)$ at $\mathrm{p}<0.05$ level of significance. Cadmium is the only trace element which exhibited the strong negative correlation at $\mathrm{p}<0.01$ for lead $(r=-0.809)$ and zinc $(r=-0.726)$ and Manganese $(r=-0.702)$ at $p<0.05$ level of significance suggesting that each paired elements have identical source or chemical phenomena, whereas the rest of the elemental pairs are not correlated with each other. Iron is the trace element which showed the positive correlation for all the metals except Cadmium and Zinc. Fe in sediment will strengthen the geochemistry of the other trace elements, which is more clearly visible from the correlation analysis. More positive correlation between metals indicated that they are probably derived from the same source. A simple correlation analysis was done to clarify the relationships between various metals. This correlation between metals synergies can exist, thus resulting in the potential compound in the field to explain the fate and transport of metals.

Correlation measures the linear relationship between random variables. The Pearson correlation matrix of trace metals in water sample (Table 12), it is observed that no significance was observed at $\mathrm{p}<0.01$ or $\mathrm{p}<0.05$ Level. Iron is positively correlated to lead, Zinc, Manganese and chromium and negatively correlated to copper, cadmium and Nickel. Manganese is also positively correlated to cr, $\mathrm{Ni}$ and $\mathrm{Zn}$ and negatively correlated to $\mathrm{Cu}, \mathrm{Cd}$ and $\mathrm{Pb}$. From our results the major contaminant as cadmium is positively correlated with $\mathrm{Ni}(\mathrm{r}=0.236)$, $\mathrm{Zn}(\mathrm{r}=0.354), \mathrm{Cu}(\mathrm{r}=0.305)$ and negatively correlated with $\mathrm{Mn}(\mathrm{r}=-0.631), \mathrm{Cr}(\mathrm{r}=-0.196), \mathrm{Fe}(\mathrm{r}=-0.159)$. The statistical analysis of the water data indicated that $\mathrm{Fe}$ is mostly of lithogenic origin.

The significant positive correlations observed between the heavy metals contents in sediment and water means that the metals in the two environmental media could have common sources. The metals probably originate from either same waste or parent material as the case may be. The metals adsorbed to the sediment are however desorbed (remobilized from the sediment) back to the water column due to changes in environmental conditions such as $\mathrm{pH}$ and redox potentials. 
Kantha Deivi Arunachalam et al. / American Journal of Environmental Science 10 (2): 102-122, 2014

Table 11. Pearson correlation matrix of trace metals in dam sediment

\begin{tabular}{llllllllll}
\hline & Copper & Chromium & Cobalt & Cadmium & Lead & Nickel & Zinc & Manganese & Iron \\
\hline Copper & 1 & 0.617 & 0.244 & -0.22 & 0.037 & 0.462 & 0.081 & -0.019 & 0.384 \\
Chromium & & 1 & 0.101 & -0.522 & 0.428 & $0.719^{*}$ & 0.535 & 0.505 & 0.188 \\
Cobalt & & & 1 & 0.019 & 0.065 & 0.194 & -0.004 & -0.16 & 0.205 \\
Cadmium & & & & 1 & $-0.809^{* *}$ & -0.275 & $-0.726^{*}$ & $-0.702^{*}$ & -0.092 \\
Lead & & & & & 1 & 0.524 & $0.907^{* *}$ & $0.784^{* *}$ & 0.077 \\
Nickel & & & & & & 1 & $0.640^{*}$ & $0.646^{*}$ & 0.434 \\
Zinc & & & & & & & 1 & $0.775^{* *}$ & -0.08 \\
Manganese & & & & & & & & 1 & 0.289 \\
Iron & & & & & & & & & 1 \\
\hline
\end{tabular}

*. Correlation is significant at the 0.05 level (2-tailed). **. Correlation is significant at the 0.01 level (2-tailed)

Table 12. Pearson correlation matrix of trace metals in dam water

\begin{tabular}{|c|c|c|c|c|c|c|c|c|}
\hline & Copper & Chromium & Cadmium & Lead & Nickel & Zinc & Manganese & Iron \\
\hline Copper & 1 & -0.04 & 0.305 & -0.079 & -0.008 & 0.014 & -0.115 & -0.484 \\
\hline Chromium & & 1.00 & -0.196 & 0.257 & 0.463 & -0.145 & 0.460 & 0.020 \\
\hline Cadmium & & & 1.000 & -0.023 & 0.236 & 0.354 & -0.631 & -0.159 \\
\hline Lead & & & & 1.000 & 0.107 & -0.617 & -0.366 & 0.302 \\
\hline Nickel & & & & & 1.000 & 0.203 & 0.286 & -0.243 \\
\hline Zinc & & & & & & 1.000 & 0.346 & 0.093 \\
\hline Manganese & & & & & & & 1.000 & 0.078 \\
\hline Iron & & & & & & & & 1.000 \\
\hline
\end{tabular}

*. Correlation is significant at the 0.05 level (2-tailed). **. Correlation is significant at the 0.01 level (2-tailed)

Table 13. Total variance and component matrices for trace metals in dam sediments

\begin{tabular}{|c|c|c|c|c|c|c|c|c|c|}
\hline \multirow[b]{2}{*}{ Component } & \multicolumn{3}{|c|}{ Initial eigenvalues } & \multicolumn{3}{|c|}{ Extraction sums of squared loadings } & \multicolumn{3}{|c|}{ Rotation sums of squared loadings } \\
\hline & Total & $\begin{array}{l}\text { Variance } \\
(\%)\end{array}$ & $\begin{array}{l}\text { Cumulative } \\
(\%)\end{array}$ & Total & $\begin{array}{l}\text { Variance } \\
(\%)\end{array}$ & $\begin{array}{l}\text { Cumulative } \\
(\%)\end{array}$ & Total & $\begin{array}{l}\text { Variance } \\
(\%)\end{array}$ & $\begin{array}{l}\text { Cumulative } \\
(\%)\end{array}$ \\
\hline 1 & 4.348 & 48.313 & 48.313 & 4.348 & 48.313 & 48.313 & 4.019 & 44.651 & 44.651 \\
\hline 2 & 1.852 & 20.578 & 68.891 & 1.852 & 20.578 & 68.891 & 2.182 & 24.240 & 68.891 \\
\hline 3 & 0.919 & 10.207 & 79.097 & & & & & & \\
\hline 4 & 0.883 & 9.811 & 88.908 & & & & & & \\
\hline 5 & 0.621 & 6.905 & 95.813 & & & & & & \\
\hline 6 & 0.255 & 2.837 & 98.650 & & & & & & \\
\hline 7 & 0.081 & 0.901 & 99.551 & & & & & & \\
\hline 8 & 0.040 & 0.449 & 100.000 & & & & & & \\
\hline 9 & 3.19E-05 & 0.000 & 100.000 & & & & & & \\
\hline
\end{tabular}

Extraction method: Principle component analysis

\subsection{Principle Component Analysis}

PCA was applied to the all the trace elements in sediment samples and described in Table 13. Due to the standardized data, the correlation matrix was used for the analysis. The principal components that have eigenvalues higher than one were extracted. The results indicate that there were two eigen values higher than one. The first and second principal component usually include a large portion of the total variance; therefore, the first two Principle
Components (PC1 and PC2) are plotted against each other and clustering of samples is possible in the effects of all variables within the two dimensional plane as represented in Fig. 4.

The PCA analysis enabled us to find the sources of the tracemetals whether it is of natural or/and anthropogenic origin. The component plot shown in Fig. 4 in rotated space for metal distribution of the sediments described that the metals lead, zinc and manganese were of natural origin and Fe can be from natural weathering of the earth's crust and rocks. The 
metals chromium and nickel which are in elevated levels along with cobalt and copper in the sediment samples can be of anthropogenic sources such as domestic activities. These results were confirmed by the repeated sampling at various seasons in the same locations. The PCA plot in rotated space for metal distribution of the sediment clearly indicated that cadmium is the only major anthropogenic element.

From Table 14 it is observed that only the first four components have eigenvalues greater than 1 , which was confirmed by Scree plot. From Fig. 5 the Component plot in rotated space for metal distribution in water sample, the metals copper, iron and zinc concentrations can be normalized together and relatively inert with respect to chemical weathering and has no significant anthropogenic source. Whereas the trace metals lead, chromium and nickel can be of migration process and are mainly lithogenous components, indicating that their metal concentrations might be controlled by external factors.

Table 14. Total variance and component matrices for trace metals in dam water

\begin{tabular}{|c|c|c|c|c|c|c|c|c|c|}
\hline \multirow[b]{2}{*}{ Component } & \multicolumn{3}{|c|}{ Initial Eigenvalues } & \multicolumn{3}{|c|}{ Extraction sums of squared loadings } & \multicolumn{3}{|c|}{ Rotation sums of squared loadings } \\
\hline & Total & $\begin{array}{l}\text { Variance } \\
(\%)\end{array}$ & $\begin{array}{l}\text { Cumulative } \\
(\%)\end{array}$ & Total & $\begin{array}{l}\text { Variance } \\
(\%)\end{array}$ & $\begin{array}{l}\text { Cumulative } \\
(\%)\end{array}$ & Total & $\begin{array}{l}\text { Variance } \\
(\%)\end{array}$ & $\begin{array}{l}\text { Cumulative } \\
(\%)\end{array}$ \\
\hline 1 & 2.079 & 25.985 & 25.985 & 2.079 & 25.985 & 25.985 & 1.887 & 23.587 & 23.587 \\
\hline 2 & 1.978 & 24.724 & 50.710 & 1.978 & 24.724 & 50.710 & 1.738 & 21.726 & 45.313 \\
\hline 3 & 1.611 & 20.132 & 70.842 & 1.611 & 20.132 & 70.842 & 1.691 & 21.140 & 66.453 \\
\hline 4 & 1.227 & 15.337 & 86.179 & 1.227 & 15.337 & 86.179 & 1.578 & 19.727 & 86.179 \\
\hline 5 & 0.637 & 7.964 & 94.143 & & & & & & \\
\hline 6 & 0.356 & 4.445 & 98.589 & & & & & & \\
\hline 7 & 0.113 & 1.408 & 99.997 & & & & & & \\
\hline 8 & 0.000 & 0.003 & 100.000 & & & & & & \\
\hline
\end{tabular}

Extraction method: Principle component analysis

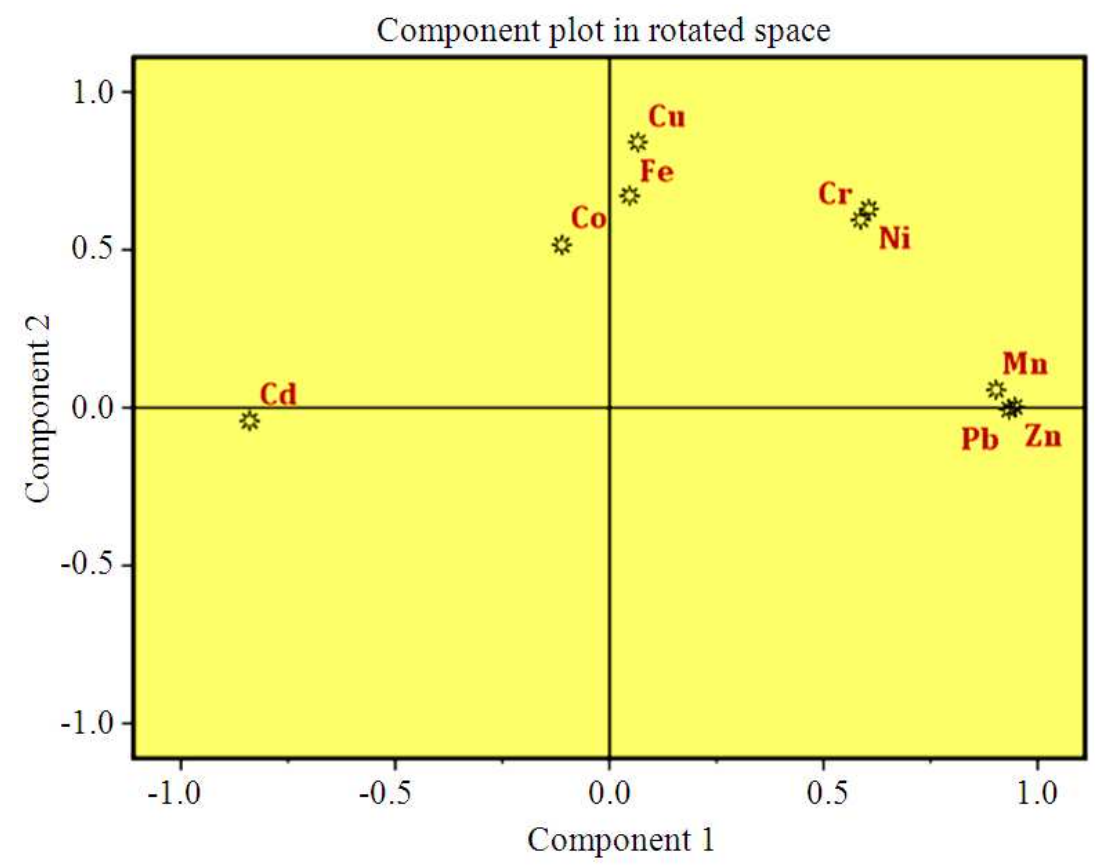

Fig. 4. Component plot in rotated space for metal distribution in the sediment 


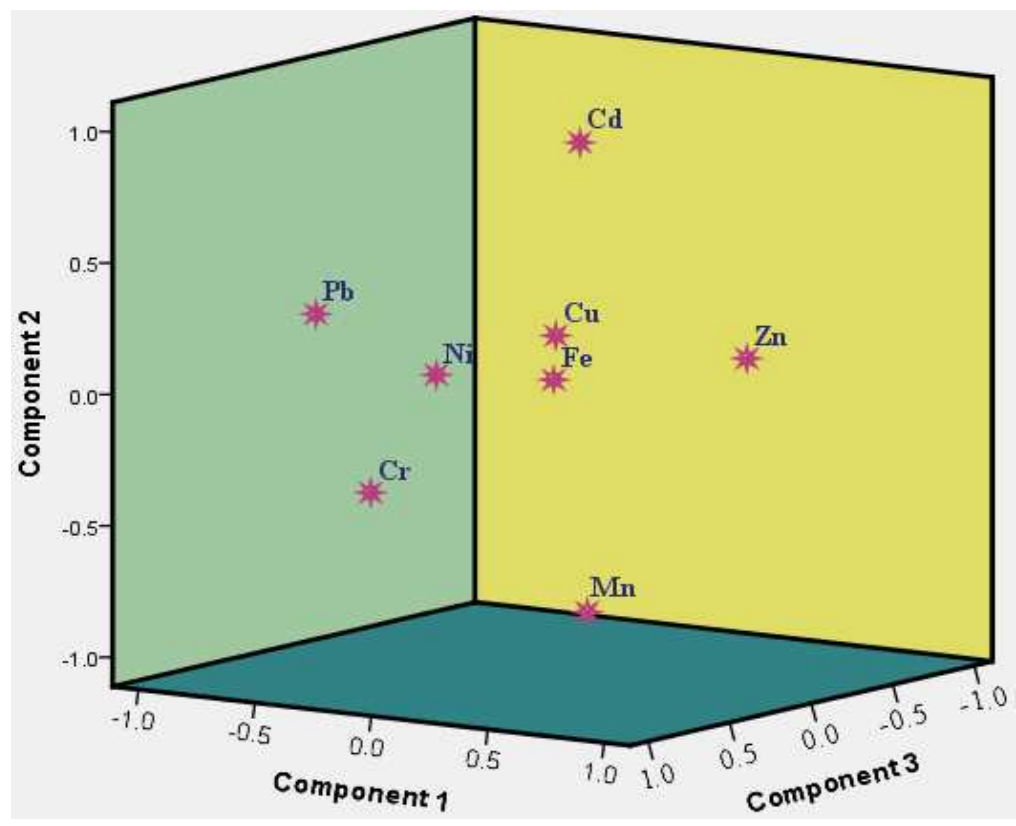

Fig. 5. Component plot in rotated space for metal distribution in the Water

\section{CONCLUSION}

The present study reveals that the water samples at different sampling positions within Nagarjuna Sagar Dam are not polluted by any of the studied Trace metals as per BIS 10500:1991 permissible limits. In addition, the deep sediment samples from Nagarjuna Sagar Dam show considerable amount of trace metal accumulation. The spatial distributions of trace elements in sediments in the estuarine environment are influenced by so many factors including geochemical and biogeochemical processes like sedimentation, precipitation and flocculation of particulate substances (Chatterjee et al., 2007). EF is widely used as an indicator to assess the status of environmental contamination. Yet, threshold values of the element enrichment have not been recognized.

The Degree of Contamination Index indicates that lead and Cadmium shows high degree of Contamination to very high degree of contamination within the dam. The Geo accumulation index classification indicates that the Trace metals chromium and cobalt is moderately contaminated and lead is highly contaminated. Considering all the criteria Cadmium is the trace elements in sediment samples is due to anthropogenic sources including fertilizers and pesticides used in agricultural activities around the sampling points SPS8 to SPS10, where agricultural activities are taking place in and around the region. GIS based spatial analysis by Inverse Distance Weighting (IDW) is an algorithm for spatially interpolating, have been proven a powerful tool to represent the distribution of trace element in sediment and water samples.

Considering all the assessment criteria, we can conclude that the sediment samples shown considerable amount of contamination of chromium, nickel, zinc and copper. The urban runoff from Srisailam to Nagarjuna Sagar Dam and the leaching effect of rivulets through areas in Lambapur and Peddagattu could be the possible reason for the Trace metal accumulation. This study is a preliminary observation of the metal concentrations within sediment and water of Nagarjuna Sagar Dam and further detailed study is required to trace the sources of contamination of these Trace metals.

\section{ACKNOWLEDGMENT}

The researchers wish to express their gratitude for research funding from the Department of Atomic Energy, Board of Research in Nuclear Science, Bhabha Atomic Research Center, Mumbai.

\subsection{Disclosure}

The authors declare no conflicts of interest in this study. 


\section{REFERENCES}

Abdel-Gawad, F.K., H.S. Ibrahim, N.S. Ammar and M. Ibrahim, 2012. Spectroscopic analyses of pollutants in water, sediment and fish. Spectrochim. Acta. A. Mol. Biomol. Spectrosc, 97: 771-7. DOI: 10.1016/j.saa.2012.07.050

Abrahim, G.M.S. and R.J. Parker, 2008. Assessment of heavy metal enrichment factors and the degree of contamination in marine sediments from Tamaki Estuary, Auckland, New Zealand. Environ. Monit. Assess, 136: 227-38. DOI: 10.1007/s 10661-007-9678-2

Acosta, J.A., A. Faz, S. Martínez-Martínez, R. Zornoza and D.M. Carmona et al., 2011. Multivariate statistical and GIS-based approach to evaluate heavy metals behavior in mine sites for future reclamation. J. Geochem. Explor, 109: 8-17. DOI: 10.1016/j.gexplo.2011.01.004

Arunachalam, K.D., S.K. Annamalai and J.K. Kuruva, 2013. In-vivo evaluation of hexavalent chromium induced DNA damage by alkaline comet assay and oxidative stress in Catla catla. Am. J. Environ. Sci., 9: 470-482. DOI : 10.3844/ajessp.2013.470.482

Barreto, W.J., D.N. Ishikawa, S. Scarminio, I. De Souza Costa and J. Dos Santos Nora et al., 2008. Fe, Mn, P and $\mathrm{S}$ Speciation in Sediments from the Capivara Hydroelectric Dam Lake (Brazil) as an Indicator of Anthropogenic Influences. CLEANSoil, Air, Water, 36: 353-359. DOI: 10.1002/clen.200700187

Biati, A., A.R. Karbassi, A.H. Hassani, S.M. Monavari and F. Moattar, 2010. Role of metal species in flocculation rate during estuarine mixing. Int. J. Environ. Sci. Technol., 7: 327-336. DOI: 10.1007/BF03326142

Brindha, K., L. Elango and R.N. Nair, 2011. Spatial and temporal variation of uranium in a shallow weathered rock aquifer in southern India. J. Earth Syst. Sci., 120: 911-920. DOI: 10.1007/s12040-011-0117-y

Cevik, F., M.Z.L. Göksu, O.B Derici and O. Findik, 2009. An assessment of metal pollution in surface sediments of Seyhan dam by using enrichment factor, geoaccumulation index and statistical analyses. Environ. Monit. Assess, 152: 309-17. DOI: 10.1007/s10661-008-0317-3

Chabukdhara, M. and A.K. Nema, 2012. Assessment of heavy metal contamination in Hindon River sediments: A chemometric and geochemical approach. Chemosphere, 87: 945-53. DOI: 10.1016/j.chemosphere.2012.01.055
Chatterjee, M., S.E.V. Filho, S.K. Sarkar, S.M. Sella and A. Bhattacharya et al., 2007. Distribution and possible source of trace elements in the sediment cores of a tropical macrotidal estuary and their ecotoxicological significance. Environ. Int., 33: 34656. DOI: 10.1016/j.envint.2006.11.013

Comero, S., S. Vaccaro and G. Locoro, 2014. Characterization of the Danube River sediments using the PMF multivariate approach. Chemosphere 95: 329-335.

Das, A. and S. Krishnaswami, 2007. Elemental geochemistry of river sediments from the Deccan Traps, India: Implications to sources of elements and their mobility during basalt-water interaction. Chem. Geol., 242: 232-254. DOI: 10.1016/j.chemgeo.2007.03.023

Delgado, J., J.M. Nieto and T. Boski, 2010. Analysis of the spatial variation of heavy metals in the Guadiana Estuary sediments (SW Iberian Peninsula) based on GIS-mapping techniques. Estuar. Coast. Shelf Sci., 88: 71-83. DOI: 10.1016/j.ecss.2010.03.011

Dobra, M., V. Viman and G. Vâtcă, 2006. Contributions to the study of heavy metals concentration variation in sedimentable dusts according to the distance from the pollution source. Am. J. Environ. Sci., 2: 92-94.

Förstner, U., 1981. Metal Pollution Assessment from Sediment Analysis. In: Metal Pollution in the Aquatic Environment SE, Springer Berlin Heidelberg, pp. 110-196.

Garizi, A.Z., V. Sheikh and A. Sadoddin, 2011. Assessment of seasonal variations of chemical characteristics in surface water using multivariate statistical methods. Int. J. Environ. Sci. Technol., 8: 581-592. DOI: 10.1007/BF03326244

Ghrefat, H. and N. Yusuf, 2006. Assessing Mn, Fe, Cu, $\mathrm{Zn}$ and $\mathrm{Cd}$ pollution in bottom sediments of Wadi Al-Arab Dam, Jordan. Chemosphere, 65: 2114-21. DOI: 10.1016/j.chemosphere.2006.06.043

Hakanson, L., 1980. An ecological risk index for aquatic pollution control.a sedimentological approach. Water Res., 14: 975-1001. DOI: 10.1016/00431354(80)90143-8

Harikumar, P.S., U.P. Nasir and M.P.M. Rahman, 2009. Distribution of heavy metals in the core sediments of a tropical wetland system. Int. J. Environ. Sci. Technol., 6: 225-232. DOI: 10.1007/BF03327626

Harzdorf, C., G. Janser, D. Rinne and M. Rogge, 1998. Application of microwave digestion to trace organoelement determination in water samples. Anal. Chim. Acta, 374: 209-214. DOI: 10.1016/S0003-2670(98)00511-X 
Hasan, A.B., S. Kabir, S.A.H.M. Reza, N.M. Zaman and A. Ahsan et al., 2013. Enrichment factor and geoaccumulation index of trace metals in sediments of the ship breaking area of Sitakund Upazilla (Bhatiary-Kumira), Chittagong, Bangladesh. J. Geochemical Explor., 125: 130-137. DOI: 10.1016/j.gexplo.2012.12.002

He, M., Z. Wang and H. Tang, 1997. Spatial and temporal patterns of acidity and heavy metals in predicting the potential for ecological impact on the Le An river polluted by acid mine drainage. Sci. Total Environ., 206: 67-77. DOI: 10.1016/S00489697(97)00217-9

Hou, D., J. He, C. Lü, L. Ren and Q. Fan et al., 2013. Distribution characteristics and potential ecological risk assessment of heavy metals $(\mathrm{Cu}, \mathrm{Pb}, \mathrm{Zn}, \mathrm{Cd})$ in water and sediments from Lake Dalinouer, China. Ecotoxicol. Environ. Saf., 93: 135-44. DOI: 10.1016/j.ecoenv.2013.03.012

Jamshidi-Zanjani, A. and M. Saeedi, 2013. Metal pollution assessment and multivariate analysis in sediment of Anzali international wetland. Environ. Earth Sci., 70: 1791-1808. DOI: 10.1007/s12665013-2267-5

Jha, S.K., G.P. Verma, S.S. Gothankar and V.D. Puranik, 2012. Transport of pollutants from nearby catchments to the Nagarjuna Sagar Dam. Radioprotection, 46: S323-S329. DOI: 10.1051/radiopro/20116984s

Jumbe, A.S. and N. Nandini, 2009. Heavy metals analysis and sediment quality values in urban lakes. Aboud S. Jumbe and N. Nandini. Am. J. Environ. Sci., 5: 678-687. DOI: 10.3844/ajessp.2009.678.687

Karadede, H. and E. Unlu, 2000. Concentrations of some heavy metals in water, sediment and rk Dam Lake (Euphrates), Turkey. Chemosphere, 41: 1371-1376. DOI: 10.1016/S0045-6535(99)00563-9

Karbassi, A.R., F. Torabi, F. Ghazban and M. Ardestani, 2011. Association of trace metals with various sedimentary phases in dam reservoirs. Int. J. Environ. Sci. Technol., 8: 841-852. DOI: 10.1007/BF03326267

Krishna, A.K., K.R. Mohan, N.N. Murthy and E.G. Group, 2011. A multivariate statistical approach for monitoring of heavy metals in sediments: A case study from wailpalli watershed, Nalgonda District Andhra Pradesh, India. Res. J. Environ. Earth Sci., 3: 103-113.
Li, F., J. Huang, G. Zeng, X. Yuan and X. Li et al., 2013. Spatial risk assessment and sources identification of heavy metals in surface sediments from the Dongting Lake, Middle China. J. Geochemical Explor., 132: 75-83. DOI: 10.1016/j.gexplo.2013.05.007

Lima, A., B. De Vivo, D. Cicchella, M. Cortini and S. Albanese, 2003. Multifractal IDW interpolation and fractal filtering method in environmental studies: An application on regional stream sediments of (Italy), Campania region. Appl. Geochemistry, 18: 18531865. DOI: 10.1016/S0883-2927(03)00083-0

Loska, K. and D. Wiechuła, 2003. Application of principal component analysis for the estimation of source of heavy metal contamination in surface sediments from the Rybnik Reservoir. Chemosphere, 51: 723-733. DOI: 10.1016/S00456535(03)00187-5

Magesh, N.S., N. Chandrasekar and V.D. Roy, 2011. Spatial analysis of trace element contamination in sediments of Tamiraparani estuary, southeast coast of India. Estuar. Coast. Shelf Sci., 92: 618-628. DOI: 10.1016/j.ecss.2011.03.001

Martins, R., M.R. Azevedo, R. Mamede, B. Sousa and R. Freitas et al., 2012. Sedimentary and geochemical characterization and provenance of the Portuguese continental shelf soft-bottom sediments. J. Mar. Syst., 91: 41-52. DOI: 10.1016/j.jmarsys.2011.09.011

Mathes, S.E. and T.C. Rasmussen, 2006. Combining multivariate statistical analysis with geographic information systems mapping: A tool for delineating groundwater contamination. Hydrogeol. J., 14: 1493-1507. DOI: 10.1007/s10040-006-0041-4

Müller, G., 1981. Schwermetallen in den Redimen des rheins, Umschau.

Muñoz-Barbosa, A., E.A. Gutiérrez-Galindo, L.W. Daesslé, M.V. Orozco-Borbón and J.A. SegoviaZavala, 2012. Relationship between metal enrichments and a biological adverse effects index in sediments from Todos Santos Bay, northwest coast of Baja California, México. Mar. Pollut. Bull., 64: 405-409. DOI: 10.1016/j.marpolbul.2011.11.023

Muratli, J.M., J. McManus, A. Mix and Z. Chase, 2012. Dissolution of fluoride complexes following microwave-assisted hydrofluoric acid digestion of marine sediments. Talanta, 89: 195-200. DOI: 10.1016/j.talanta.2011.11.081 
Nobi, E.P., E. Dilipan, T. Thangaradjou, K. Sivakumar and L. Kannan, 2010. Geochemical and geostatistical assessment of heavy metal concentration in the sediments of different coastal ecosystems of Andaman Islands, India. Estuar. Coast. Shelf Sci., 87: 253-264. DOI: 10.1016/j.ecss.2009.12.019

Ong, M.C., K. Terengganu, I. Islamic, 2009. An assessment of metals $(\mathrm{Pb}$ and $\mathrm{Cu})$ contamination in bottom sediment from South China Sea Coastal waters, Malaysia. Am. J. Appl. Sci., 6: 1418-1423. DOI: 10.3844/ajassp.2009.1418.1423

Orebiyi, E.O., J.A. Awomeso, O.A. Idowu, O. Martins and O. Oguntoke et al., 2010. Assessment of pollution hazards of shallow well water in abeokuta and environs, Southwest, Nigeria. Am. J. Environ. Sci., 6: 50-56. DOI : 10.3844/ajessp.2010.50.56

Oyoo-Okoth, E., W. Admiraal, O. Osano, V. Ngure and M.H.S. Kraak et al., 2010. Monitoring exposure to heavy metals among children in Lake Victoria, Kenya: Environmental and fish matrix. Ecotoxicol. Environ. Saf., 73: 1797-1803. DOI: 10.1016/j.ecoenv.2010.07.040

Qiao, Y., Y. Yang, J. Zhao, R. Tao and R. Xu, 2013. Influence of urbanization and industrialization on metal enrichment of sediment cores from Shantou Bay, South China. Environ. Pollut., 182: 28-36. DOI: 10.1016/j.envpol.2013.06.044

Raghavendra, T., K. Srilatha, C. Mahender, M. Elander and T. Vijayalakshmi et al., 2013. Distribution of uranium concentration in ground water samples from the Peddagattu/Nambapur and Seripally regions using laser. Radiat. Prot. Dosimetry, pp: 1-6.

Ramesh, R., V. Subramanian, N. Delhi and R.V.A.N. Grieken, 1990. Heavy Metal Distribution in Sediments of Krishna River Basin, India. Environ. Geol. Water Sci., 15: 207-216. DOI: 10.1007/BF01706412

Reddy, V.K.K., B.S. Reddy, M.S. Reddy, C.G. Reddy and P.Y. Reddy et al., 2003. Baseline studies of radon/thoron concentration levels in and around the Lambapur and Peddagattu areas in Nalgonda district Andhra Pradesh, India. Radiat. Meas., 36: 419-423. DOI: 10.1016/S1350-4487(03)00191-4

Sartandel, S.J., S.K. Jha, S.V. Bara, R.M. Tripathi and V.D. Puranik, 2009. Spatial distribution of uranium and thorium in the surface soil around proposed uranium mining site at Lambapur and its vertical profile in the Nagarjuna Sagar Dam. J. Environ. Radioact., 100: 831-834. DOI: 10.1016/j.jenvrad.2009.06.005
Stoffers, P., G.P. Glasby, C.J. Wilson, K.R. Davis and P. Walter, 1986. Heavy metal pollution in Wellington Harbour. New Zeal. J. Mar. Freshw. Res., 20: 495512. DOI: 10.1080/00288330.1986.9516169

Suresh, G., P. Sutharsan, V. Ramasamy and R. Venkatachalapathy, 2012. Assessment of spatial distribution and potential ecological risk of the heavy metals in relation to granulometric contents of Veeranam lake sediments, India. Ecotoxicol. Environ. Saf., 84: 117-124. DOI: 10.1016/j.ecoenv.2012.06.027

Tang, W., Y. Zhao, C. Wang, B. Shan and J. Cui, 2013. Heavy metal contamination of overlying waters and bed sediments of Haihe Basin in China. Ecotoxicol. Environ. Saf., 98: 317-323. DOI: 10.1016/j.ecoenv.2013.09.038

Taylor, S.R., 1964. Abundance of chemical elements in the continental crust: A new table. Geochim. Cosmochim. Acta, 28: 1273-1285. DOI: 10.1016/0016-7037(64)90129-2

Tomlinson, D.L., J.G. Wilson, C.R. Harris and D.W. Jeffrey, 1980. Problems in the assessment of heavymetal levels in estuaries and the formation of a pollution index. Helgoländer Meeresuntersuchungen, 33: 566-575. DOI: $10.1007 / \mathrm{BF} 02414780$

Turekian, K.K. and K.H. Wedepohl, 1961. Distribution of the elements in some major units of the earth's crust. Geol. Soc. Am. Bull., DOI: 10.1130/00167606(1961)72[175: DOTEIS]2.0.CO;2

Varol, M., 2011. Assessment of heavy metal contamination in sediments of the Tigris River (Turkey) using pollution indices and multivariate statistical techniques. J. Hazard. Mater., 195: 355364. DOI: 10.1016/j.jhazmat.2011.08.051

Verma, M.B., P.S. Dandele, G.N. Babu, K.U. Magheswar and P.B. Maithani, 2011. Hydrouranium anomalies as an effective tool in exploration of concealed unconformity related u-deposit in Srisailam sub-basin Andhra Pradesh-case study from Chitrial area. J. Geol. Soc. Ind., 78: 468-476. DOI: 10.1007/s12594-011-0108-2

Vinodhini, R. and M. Narayanan, 2008. Bioaccumulation of heavy metals in organs of fresh water fish Cyprinus Carpio (Common carp). Int. J. Environ. Sci. Technol., 5: 179-182. DOI: 10.1007/BF03326011

Wang, C., S. Liu, Q. Zhao, L. Deng and S. Dong, 2012. Spatial variation and contamination assessment of heavy metals in sediments in the Manwan Reservoir, Lancang River. Ecotoxicol. Environ. Saf., 82: 32-39. DOI: 10.1016/j.ecoenv.2012.05.006 
Wang, X.C., H. Feng and H.Q. Ma, 2007. Assessment of Metal Contamination in Surface Sediments of Jiaozhou Bay, Qingdao, China. CLEAN-Soil, Air, Water, 35: 62-70. DOI: 10.1002/clen.200600022

Zahra, A., M.Z. Hashmi, R.N. Malik and Z. Ahmed, 2014. Enrichment and geo-accumulation of heavy metals and risk assessment of sediments of the Kurang Nallah-Feeding tributary of the Rawal Lake Reservoir, Pakistan. Sci. Total Environ., 470: 92533. DOI: 10.1016/j.scitotenv.2013.10.017

Zakir, H.M., N. Shikazona and K.A. Otomo, 2008. Geochemical distribution of trace metals and assessment of anthropogenic pollution in sediments of old Nakagawa River, Tokyo, Japan laboratory of geochemistry, school of science for open and environmental systems, faculty of science and technology. K. Am. J. Environ. Sci., 4: 654-665. DOI: 10.3844/ajessp.2008.654.665
Zamani-Ahmadmahmoodi, R., A. Esmaili-Sari, J. Mohammadi, A.R. Bakhtiari and M. Savabieasfahani, 2013. Spatial distribution of cadmium and lead in the sediments of the western Anzali wetlands on the coast of the Caspian Sea (Iran). Mar. Pollut. Bull., 74: 464-70. DOI: 10.1016/j.marpolbul.2013.06.009

Zhang, L. and H. Shao, 2013. Heavy Metal Pollution in Sediments from Aquatic Ecosystems in China. CLEAN-Soil, Air, Water, 41: 878-882. DOI: 10.1002/clen.201200565 